\title{
Seasonal Dynamics in Dissolved Organic Matter, Hydrogen Peroxide, and Cyanobacterial Blooms in Lake Erie
}

Rose M. Cory ${ }^{1 *}$, Timothy W. Davis ${ }^{2}$, Gregory J. Dick ${ }^{1,3}$, Thomas Johengen ${ }^{4}$, Vincent J. Denef ${ }^{3}$, Michelle A. Berry ${ }^{3}$, Sarah E. Page ${ }^{1+}$, Susan B. Watson ${ }^{5}$, Kate Yuhas ${ }^{1}$ and George W. Kling ${ }^{3}$

\begin{abstract}
${ }^{1}$ Department of Earth and Environmental Sciences, University of Michigan, Ann Arbor, MI, USA, ${ }^{2}$ Great Lakes Environmental Research Laboratory, National Oceanic and Atmospheric Administration, Ann Arbor, MI, USA, ${ }^{3}$ Department of Ecology and Evolutionary Biology, University of Michigan, Ann Arbor, MI, USA, ${ }^{4}$ Cooperative Institute for Limnology and Ecosystems Research, Ann Arbor, MI, USA, ${ }^{5}$ Canada Centre for Inland Waters, Environment and Climate Change Canada, Burlington, ON, Canada
\end{abstract}

OPEN ACCESS

Edited by:

Colleen Hansel,

Woods Hole Oceanographic

Institution, USA

Reviewed by:

Jun Sun,

Tianjin University of Science and

Technology, China

Hongmei Chen,

Oak Ridge National Laboratory, USA

*Correspondence:

Rose M. Cory

rmcory@umich.edu

${ }^{\dagger}$ Present Address:

Sarah E. Page,

Arcadis U.S., Inc., Minneapolis, MN,

Specialty section:

This article was submitted to Marine Biogeochemistry,

a section of the journal Frontiers in Marine Science

Received: 15 January 2016 Accepted: 07 April 2016 Published: 26 April 2016

Citation:

Cory RM, Davis TW, Dick GJ, Johengen T, Denef VJ, Berry MA, Page SE, Watson SB, Yuhas $K$ and Kling GW (2016) Seasonal Dynamics in Dissolved Organic Matter, Hydrogen Peroxide, and Cyanobacterial Blooms in Lake Erie. Front. Mar. Sci. 3:54. doi: 10.3389/fmars.2016.00054
Hydrogen peroxide $\left(\mathrm{H}_{2} \mathrm{O}_{2}\right)$ has been suggested to influence cyanobacterial community structure and toxicity. However, no study has investigated $\mathrm{H}_{2} \mathrm{O}_{2}$ concentrations in freshwaters relative to cyanobacterial blooms when sources and sinks of $\mathrm{H}_{2} \mathrm{O}_{2}$ may be highly variable. For example, photochemical production of $\mathrm{H}_{2} \mathrm{O}_{2}$ from chromophoric dissolved organic matter (CDOM) may vary over the course of the bloom with changing CDOM and UV light in the water column, while microbial sources and sinks of $\mathrm{H}_{2} \mathrm{O}_{2}$ may change with community biomass and composition. To assess relationships between $\mathrm{H}_{2} \mathrm{O}_{2}$ and harmful algal blooms dominated by toxic cyanobacteria in the western basin of Lake Erie, we measured $\mathrm{H}_{2} \mathrm{O}_{2}$ weekly at six stations from June to November, 2014 and 2015, with supporting physical, chemical, and biological water quality data. Nine additional stations across the western, eastern, and central basins of Lake Erie were sampled during August and October, 2015. CDOM sources were quantified from the fluorescence fraction of CDOM using parallel factor analysis (PARAFAC). CDOM concentration and source were significantly correlated with specific conductivity, demonstrating that discharge of terrestrially-derived CDOM from rivers can be tracked in the lake. Autochthonous sources of CDOM in the lake increased over the course of the blooms. Concentrations of $\mathrm{H}_{2} \mathrm{O}_{2}$ in Lake Erie ranged from $47 \pm 16 \mathrm{nM}$ to $1570 \pm 16 \mathrm{nM}$ (average of $371 \pm 17 \mathrm{nM} ; n=225$ ), and were not correlated to CDOM concentration or source, UV light, or estimates of photochemical production of $\mathrm{H}_{2} \mathrm{O}_{2}$ by CDOM. Temporal patterns in $\mathrm{H}_{2} \mathrm{O}_{2}$ were more closely aligned with bloom dynamics in the lake. In 2014 and 2015, maximum concentrations of $\mathrm{H}_{2} \mathrm{O}_{2}$ were observed prior to peak water column respiration and chlorophyll $a$, coinciding with the onset of the widespread Microcystis blooms in late July. The spatial and temporal patterns in $\mathrm{H}_{2} \mathrm{O}_{2}$ concentrations suggested that production and decay of $\mathrm{H}_{2} \mathrm{O}_{2}$ from aquatic microorganisms can be greater than photochemical production of $\mathrm{H}_{2} \mathrm{O}_{2}$ from CDOM and abiotic decay pathways. Our study measured $\mathrm{H}_{2} \mathrm{O}_{2}$ concentrations in the range where physiological impacts on cyanobacteria have been reported, suggesting that $\mathrm{H}_{2} \mathrm{O}_{2}$ could influence the structure and function of cyanobacterial communities in Lake Erie.

Keywords: Hydrogen Peroxide, Lake Erie, cyanobacteria, Microcystis aeruginosa, microcystins, harmful algal blooms, Great Lakes, CDOM 


\section{INTRODUCTION}

Hydrogen peroxide $\left(\mathrm{H}_{2} \mathrm{O}_{2}\right)$ is an oxidative stressor to aquatic microorganisms (Lesser, 2006; Drábková et al., 2007), and its ubiquitous presence in surface waters (Petasne and Zika, 1987; Cooper et al., 1989, 1994) has been proposed to influence the community composition and toxicity of cyanobacterial harmful algal blooms (CHABs; Qian et al., 2010, 2012; Dziallas and Grossart, 2011; Paerl and Otten, 2013). In experimental work on whole bloom communities, addition of $\mathrm{H}_{2} \mathrm{O}_{2}(60 \mu \mathrm{M})$ resulted in selective killing of cyanobacteria as eukaryotic phytoplankton, zooplankton and macrofauna did not seem to be affected (Matthijs et al., 2012). The toxin microcystin, produced by some strains of $M$. aeruginosa and many other cyanobacterial species (O’Neil et al., 2012), has been hypothesized to protect against $\mathrm{H}_{2} \mathrm{O}_{2}$ (Paerl and Otten, 2013). For example, in lab cultures it was found that a microcystin-producing strain of $M$. aeruginosa better tolerated high $\mathrm{H}_{2} \mathrm{O}_{2}$ concentrations than a non-microcystin-producing mutant of the same strain (Zilliges et al., 2011). Leunert et al. (2014) showed that a non-toxic strain of M.aeruginosa exhibited a physiological response to $\mathrm{H}_{2} \mathrm{O}_{2}$ concentrations as low as $50 \mathrm{nM}$, within the range of concentrations reported in surface waters (Cooper et al., 1994; Burns et al., 2012), while the toxic strain tolerated 10 times more $\mathrm{H}_{2} \mathrm{O}_{2}$. However, others have shown a more variable response of $M$. aeruginosa to $\mathrm{H}_{2} \mathrm{O}_{2}$ by strain and by $\mathrm{H}_{2} \mathrm{O}_{2}$ concentration, with responses varying between toxic and non-toxic strains of $M$. aeruginosa and by $\mathrm{H}_{2} \mathrm{O}_{2}$ concentration (Dziallas and Grossart, 2011).

While evidence from laboratory culture studies suggests that $\mathrm{H}_{2} \mathrm{O}_{2}$ has an effect on toxicity of $M$. aeruginosa, it is difficult to relate these findings to natural surface waters due to lack of information on the concentration of $\mathrm{H}_{2} \mathrm{O}_{2}$ that cyanobacteria may be exposed to during the course of a bloom. Predicting $\mathrm{H}_{2} \mathrm{O}_{2}$ concentrations during a bloom is not currently possible because sources and sinks of $\mathrm{H}_{2} \mathrm{O}_{2}$ are broader and more dynamic than previously recognized (Cooper et al., 1994; Vermilyea et al., 2010; Diaz et al., 2013; Marsico et al., 2015). Until recently, the dominant source of $\mathrm{H}_{2} \mathrm{O}_{2}$ in surface waters was thought to be from dissolved organic matter (DOM) interacting with UV light. Specifically, $\mathrm{H}_{2} \mathrm{O}_{2}$ is produced in all sunlit surface waters upon UV-light absorption by the chromophoric fraction of DOM (CDOM) (Petasne and Zika, 1987; Cooper et al., 1989). Variability in CDOM concentration and source affects the rate of UV light absorption and the depth of light penetration in the water column, which in turn control the photochemical production of $\mathrm{H}_{2} \mathrm{O}_{2}$ (Miller, 1998). Thus, knowing the concentration of CDOM and the apparent quantum yield for photochemical formation of $\mathrm{H}_{2} \mathrm{O}_{2}$ by CDOM, production of $\mathrm{H}_{2} \mathrm{O}_{2}$ in surface waters can be modeled as a function of depth, date, or latitude (Jerome and Bukata, 1998; Andrews et al., 2000; Kieber et al., 2014). Given strong gradients in CDOM in lakes or coastal waters related to riverine loading of terrestrially-derived CDOM (Minor and Stephens, 2008; Murphy et al., 2008; Abdulla et al., 2010; Stephens and Minor, 2010), variability in photochemical production of $\mathrm{H}_{2} \mathrm{O}_{2}$ in surface waters has also been suggested to be related to riverine discharge of CDOM (Andrews et al., 2000; O'Sullivan et al., 2005). Predicting $\mathrm{H}_{2} \mathrm{O}_{2}$ concentrations is more difficult in CHABs-impacted waters compared with coastal or open seawater due to high biological activity, which may decrease the total amount and the fraction of UV light absorption by CDOM in the water column, and possibly more importantly, due to increased biological production and decay of $\mathrm{H}_{2} \mathrm{O}_{2}$ (Dixon et al., 2013).

Research on the biological production of $\mathrm{H}_{2} \mathrm{O}_{2}$ has increased with the recognition that aerobic metabolism generates $\mathrm{H}_{2} \mathrm{O}_{2}$ and other reactive oxygen species (ROS) (Apel and Hirt, 2004). Biological sources of $\mathrm{H}_{2} \mathrm{O}_{2}$ have now been recognized as ubiquitous in the dark and sunlit water columns of streams, lakes, and coastal waters (Vermilyea et al., 2010; Diaz et al., 2013; Dixon et al., 2013; Winterbourn, 2013; Marsico et al., 2015). In addition, comparisons of photochemical to biological production rates of $\mathrm{H}_{2} \mathrm{O}_{2}$ have demonstrated that production of $\mathrm{H}_{2} \mathrm{O}_{2}$ by bacteria and algae may constitute a substantial fraction of the total $\mathrm{H}_{2} \mathrm{O}_{2}$ present in fresh and marine waters (Vermilyea et al., 2010; Dixon et al., 2013). Although the controls on biological production and decay of $\mathrm{H}_{2} \mathrm{O}_{2}$ in natural waters remain poorly understood, in general they have been proposed to depend on light and the abundance of microbial biomass (Zepp et al., 1987; Marsico et al., 2015). Thus, biological production may dominate over photochemical production of $\mathrm{H}_{2} \mathrm{O}_{2}$ by CDOM especially in particle-rich eutrophic waters characterized by high rates of respiration and potentially low rates of UV light absorption by CDOM.

While biological production of $\mathrm{H}_{2} \mathrm{O}_{2}$ could be high during a bloom, biological decay, the main sink for $\mathrm{H}_{2} \mathrm{O}_{2}$ in fresh and marine waters (Moffett and Zafiriou, 1990; Cooper et al., 1994), may also increase over the course of a bloom because rates of biological decay have been positively correlated with measures of microbial biomass (e.g., bacterial, algal, and total cell abundance; Marsico et al., 2015). The relationship between biological decay of $\mathrm{H}_{2} \mathrm{O}_{2}$ and biomass is consistent with the notion that many organisms have similar enzymatic capacity to break down $\mathrm{H}_{2} \mathrm{O}_{2}$ (i.e., catalase and peroxidase) (Moffett and Zafiriou, 1990; Cooper et al., 1994). Given the evidence that heterotrophic bacteria may be primarily responsible for $\mathrm{H}_{2} \mathrm{O}_{2}$ decay (Cooper et al., 1994), rates of biological decay may also depend on the availability of labile carbon (i.e., DOM) for bacteria. Therefore, DOM may influence $\mathrm{H}_{2} \mathrm{O}_{2}$ in natural waters both through photochemical production by CDOM, and also by fueling bacterial respiration and production (Wetzel, 1992).

Both the light-absorbing properties of CDOM and lability of DOM to bacteria depend on its sources and chemical composition (Cory and McKnight, 2005; Cory and Kaplan, 2012; Sleighter et al., 2014). These properties of DOM may vary in space and time in relation to proximity of riverine sources that deliver terrestrially-derived DOM rich in light-absorbing CDOM to lakes (Abdulla et al., 2010; Peterson et al., 2012), or over the course of a bloom as DOM source and composition shifts to more autochthonous carbon that is less light absorbing (Zhang et al., 2014) but likely more labile to bacteria (Cory and Kaplan, 2012; Hosen et al., 2014).

Understanding the potential influence of $\mathrm{H}_{2} \mathrm{O}_{2}$ on $\mathrm{CHAB}$ events is important given that these events in lakes and coastal 
waters are expected to worsen with climate or land-use change (O'Neil et al., 2012; Michalak et al., 2013; Paerl and Otten, 2013). Yet no study has examined the potential interactions between CDOM and $\mathrm{H}_{2} \mathrm{O}_{2}$ over the course of a bloom. To address this knowledge gap, we studied the spatial and temporal variability in $\mathrm{H}_{2} \mathrm{O}_{2}$ and $\mathrm{CDOM}$ concentration and sources approximately weekly across the western basin of Lake Erie from June to October and throughout Lake Erie in 2014 and 2015. Lake Erie is the most susceptible of the Laurentian Great Lakes to eutrophication and CHABs due to extensive anthropogenic nutrient inputs, warm summer temperatures, and shallow depth (Steffen et al., 2014). Within Lake Erie, CHABs have occurred annually since the mid-1990s, with blooms most frequently observed in the western basin (Brittain et al., 2000; Ouellette et al., 2006; Rinta-Kanto et al., 2009) that appear to be increasing in severity (Obenour et al., 2014). In the last 5 years Lake Erie has experienced two of the largest recorded blooms in its history (in 2011; Michalak et al., 2013; and in 2015), and in 2014, elevated concentrations of microcystins, shut down the drinking water supply to nearly a half million people in and around Toledo, $\mathrm{OH}$ for just over 2 days.

In this study, we measured $\mathrm{H}_{2} \mathrm{O}_{2}$ concentrations in Lake Erie and in field experiments, and combined these data with information from the literature to estimate photochemical and biological production and decay of $\mathrm{H}_{2} \mathrm{O}_{2}$. We concurrently measured CDOM and characterized its sources and composition using optical proxies including excitation emission matrices (EEMs) and parallel factor analysis (PARAFAC; Stedmon et al., 2003), which provide information on at least three types of carbon varying in source and lability to bacteria (Cory and McKnight, 2005; Cory and Kaplan, 2012). Biological activity over the course of the bloom in Lake Erie was characterized using whole water respiration rates, chlorophyll $a$, and particulate microcystins along with a suite of supporting water quality measurements. We present several lines of evidence for the importance of biological controls and responses to the $\mathrm{H}_{2} \mathrm{O}_{2}$ concentrations in Lake Erie.

\section{MATERIALS AND METHODS \\ Site Description}

The western basin of Lake Erie is about one-fifth of the total lake surface area, the fourth largest lake in North America. The mean water depth of stations sampled in the western basin was $6 \mathrm{~m}$, ranging from $\sim 2-3 \mathrm{~m}$ at station 6 to $7-9 \mathrm{~m}$ at stations 4 and 13 (Figure 1), representative of the average depth of the western basin (7.4 m; O'Donnell et al., 2010). The waters of the western basin are more sediment and nutrient rich than other basins in the lake (and compared to other Great Lakes), due to the large loads from the Detroit and Maumee Rivers and due to re-suspension (Michalak et al., 2013). For example, the agricultural-dominated Maumee River system delivers nitrogen and phosphorus from farmland fertilizer that has been implicated in the increasing prevalence of CHABS. CHABs in western Lake Erie develop during summer months (Rinta-Kanto et al., 2005; Bridgeman et al., 2012) and in the open waters are generally dominated by the cyanobacterium, Microcystis (RintaKanto et al., 2005). However, tributaries into Sandusky Bay, and the Maumee River, are dominated by the cyanobacterium Planktothrix (Conroy et al., 2007; Kutovaya et al., 2012; Davis et al., 2015). Both cyanobacteria are the primary toxin producers in the open waters and tributaries, respectively (Rinta-Kanto et al., 2009; Kutovaya et al., 2012; Davis et al., 2014).

\section{Sample Collection and Supporting Water Quality Analysis}

In 2014 and 2015, samples were collected weekly from six sites in the western basin of Lake Erie (Figure 1) from June through October. In 2014, water samples were also collected from several of these sites in May. Water samples were collected using a peristaltic pump and tygon tubing deployed from the ship deck to collect a surface integrated water sample (over the top 2 $3 \mathrm{~m}$ of the water column for sites in the western basin). On two dates (25 August and 18 September 2014), waters samples were collected in the western basin at Stations 2, 4, and 12 from two depths in the water column: "surface" $(0.1 \mathrm{~m})$, and "deep" (4$7 \mathrm{~m}$, depending on the station). In August and October 2015, water samples were collected during the Lake Erie CCGS Limnos cruises from nine sites in the western basin, three in the central basin, and two in the eastern basin (Figure 1). Water samples for the Limnos cruises were collected using a rosette from a depth of $1 \mathrm{~m}$, and at selected sites also from one meter above the bottom (with bottom depths ranging from 10 - $61 \mathrm{~m}$ depending on the site). Temperature, specific conductivity, turbidity, and photosynthetically active radiation (PAR) were measured using a CTD deck-board profiler. Water column $\mathrm{pH}$ was measured on the ship deck from unfiltered, whole water immediately after sample collection using a standard lab probe calibrated the morning of the cruise with standard buffer solutions ( $\mathrm{pH} 4.0,7.0$, and 10.0, Fisher Scientific).

\section{CDOM Characterization}

Absorption coefficients of CDOM and optical proxies for CDOM source and composition were analyzed on GF/F-filtered water using an Aqualog (Horiba Scientific) using 1-cm quartz cuvettes. For lake water samples with relatively low CDOM concentrations, CDOM spectra were analyzed using a 5 or $10-\mathrm{cm}$ quartz cuvette on a UV-Vis spectrophotometer (Cary Varian 300). The spectral slope $\left(S_{R}\right)$ ratio of CDOM, a proxy for the average molecular weight of DOM, was calculated from the absorbance spectrum of each sample (Helms et al., 2008). Naperian absorption coefficients of $\operatorname{CDOM}\left(a_{\operatorname{CDOM} \lambda}\right)$ were calculated as follows:

$$
a C D O M_{\lambda}=\frac{A_{\lambda}}{l} 2.303
$$

where $A$ is the absorbance reading and $l$ is the path length in meters. SUVA 254 was calculated following (Weishaar et al., 2003) where absorbance readings at $254 \mathrm{~nm}$ were divided by the cuvette pathlength $(\mathrm{m})$ and then divided by the DOC concentration $(\mathrm{mg}$ $\mathrm{C} \mathrm{L}^{-1}$; Table 1).

Fluorescence spectra of CDOM were measured from excitation-emission matrices (EEMs) analyzed on water samples 


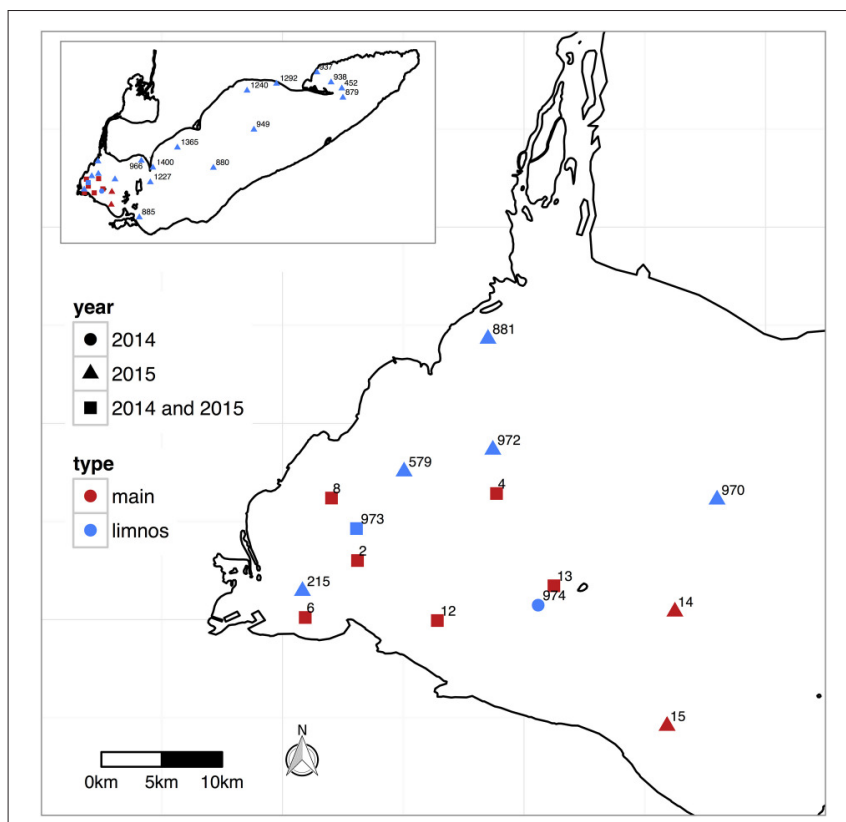

FIGURE 1 | Stations sampled in Lake Erie during 2014 and 2015 identified by site ID number, with "main" corresponding the stations sampled weekly during summer 2014 and 2015, and "limnos" corresponding to the stations sampled on the CCGS Limnos cruises during August and September 2014 and August and October, 2015.

TABLE 1 | Physical, chemical, biological water quality of the western basin in Lake Erie.

\begin{tabular}{|c|c|}
\hline Parameter & ${ }^{\mathrm{a}}$ Average \pm SE $(\boldsymbol{n})$ \\
\hline Temperature $\left({ }^{\circ} \mathrm{C}\right)$ & $19 \pm 1(201)$ \\
\hline Specific conductivity $(\mu \mathrm{S} \mathrm{cm}-1)$ & $263 \pm 6(201)$ \\
\hline $\mathrm{pH}$ & $8.58 \pm 0.04(126)$ \\
\hline Photosynthetically active radiation (PAR) $\left(\mu \mathrm{E} \mathrm{cm}{ }^{-2} s^{-1}\right)$ & $376 \pm 30(257)$ \\
\hline Chlorophyll a ( $\left.\mu \mathrm{g} \mathrm{L}^{-1}\right)$ & $33 \pm 3(201)$ \\
\hline Dissolved oxygen $\left(\mathrm{mg} \mathrm{L}^{-1}\right)$ & $7.7 \pm 0.2(201)$ \\
\hline $\mathrm{H}_{2} \mathrm{O}_{2}(\mathrm{nM})$ & $371 \pm 17(225)$ \\
\hline \multicolumn{2}{|l|}{ DOM CHARACTERIZATION } \\
\hline $\mathrm{DOC}(\mu \mathrm{M})$ & $399 \pm 9(133)$ \\
\hline$a_{305}\left(m^{-1}\right)$ & $6.7 \pm 0.4(257)$ \\
\hline$S_{R}$ (spectral slope ratio) & $1.26 \pm 0.02(257)$ \\
\hline Fluorescence index (Fl) & $1.59 \pm 0.01(257)$ \\
\hline SUVA $_{254}\left(\mathrm{Lmg} \mathrm{C}^{-1} \mathrm{~m}^{-1}\right)$ & $1.16 \pm 0.04(133)$ \\
\hline
\end{tabular}

FI, fluorescence index; $S_{R}$, spectral slope ratio, SUVA 254 , specific UV absorbance. a all values presented as average \pm standard error (SE).

with an Aqualog following (Cory et al., 2010b). EEMs were corrected for inner-filter effects and for instrument-specific excitation and emission corrections in Matlab (version 7.7) following Cory et al. (2010b). The fluorescence index (FI; McKnight et al., 2001) was calculated from each corrected EEM as the ratio of emission intensity at $470 \mathrm{~nm}$ over the emission intensity at $520 \mathrm{~nm}$ at an excitation wavelength of $370 \mathrm{~nm}$ (Cory et al., 2010b).
PARAFAC was employed to separate the dataset of 260 Lake Erie EEMs into mathematically and chemically-independent components (each representing a single fluorophore or a group of strongly co-varying fluorophores) multiplied by their excitation and emission spectra (representing either pure or combined spectra). The result is a reduction of the 3-dimensional EEM data into 2-dimensional spectra representing chemically independent components (Stedmon et al., 2003; Stedmon and Bro, 2008). A PARAFAC model allows identification of the underlying structure of a dataset of EEMs, but the components identified likely do not correspond to pure spectra. In a complex mixture such as CDOM, components represent spectra of chemically similar fluorophores or groups of fluorophores that strongly covary under the experimental conditions (Stedmon et al., 2003; Stedmon and Bro, 2008). The PARAFAC model was generated and validated following the procedures in Stedmon and Bro (2008) using the DrEEM Toolbox in Matlab V 7.7 (Murphy et al., 2013).

Briefly, the dataset of 260 EEMs from Lake Erie was normalized to unit intensity during the model tests to reduce the concentration-related collinearity of the components and to allow low concentration samples to influence the model (Murphy et al., 2013). Excitation wavelengths were $252-450 \mathrm{~nm}$ in $2-\mathrm{nm}$ increments, while emission wavelengths ranged from 305 to $500 \mathrm{~nm}$ in $1-\mathrm{nm}$ increments. During the exploratory analysis, model runs were evaluated for three to six components. Modeled, measured, and residual EEMs were visually examined for model fit and outliers, with five samples removed as outliers. A four component model was validated (Figure 2) using a multi-split analysis: 255 EEMs were split by alternating split style into six different datasets that were modeled independently from one another (Murphy et al., 2013). All three validation tests passed from the six-way-split validation. The model explained $99.8 \%$ of the variation within the dataset, with variation explained by each component decreasing in order from component one to component four (C1 through $\mathrm{C} 4) . F_{\max }$ values were used to quantify relative concentration of each component in a water sample (Stedmon et al., 2003; Murphy et al., 2013), which is the fluorescence of each component at the respective excitation and emission maximum (Table 2).

\section{UV Absorbance and Attenuation in Lake Erie}

To determine the fraction of UV light absorbed by CDOM relative to all UV light-absorbing constituents in Lake Erie, the absorbance of unfiltered whole water was measured from each station visited during the weekly cruises between 25 August and 3 November 2014. Whole water samples were analyzed using a diffuse-reflectance accessory (Cary 5000, Varian Inc.). The absorption spectrum of the whole water $\left(a_{\mathrm{tot}, \lambda}\right)$ was determined by subtracting the reflectance from the transmittance of the suspension; this method corrects for the influence of light scattering on the absorption properties of suspended particles (Tassan and Ferrari, 2003).

UV light attenuation was measured in-situ in Lake Erie as a function of depth at several stations in June, August, and 

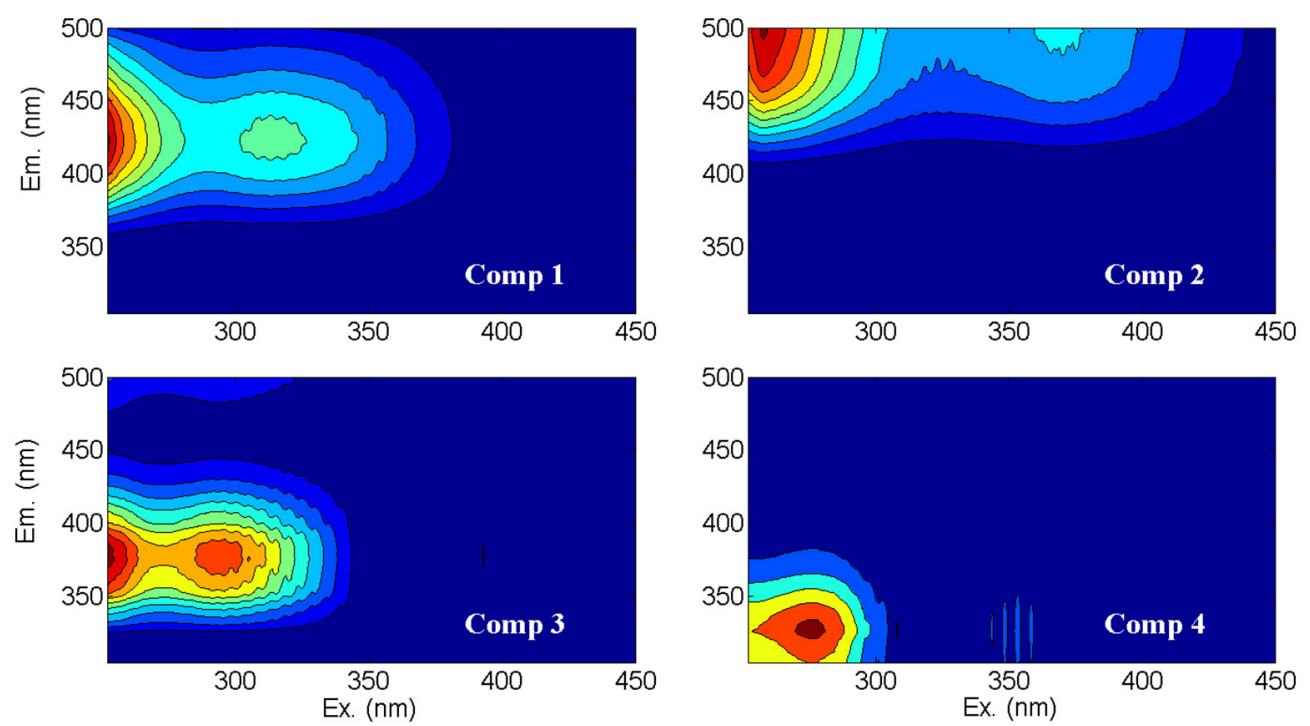

FIGURE 2 | Contour plots of the fluorescent spectra of the four CDOM components (Comp 1 through Comp 4) identified by PARAFAC analysis of Lake Erie EEMs. The model explained $99.8 \%$ of the variation within the dataset, with variation explained by each component decreasing in order from component one to component four. Component descriptions and likely sources are in Table 2.

TABLE 2 | Fluorescence characteristics of Lake Erie water.

\begin{tabular}{|c|c|c|c|c|}
\hline Component No. & $\lambda_{\mathrm{Ex}}(\mathrm{nm})$ & $\lambda_{\mathrm{Em}}(\mathrm{nm})$ & EEM region ${ }^{a}$ & Description; likely source(s) ${ }^{a-c}$ \\
\hline 1 & $250(315)$ & 420 & Peak M & Microbial humic, associated with fresh autochthonous C \\
\hline 2 & $250(370)$ & $>470$ & Peak A & Terrestrial humic; associated with soil organic \\
\hline 3 & $250(290)$ & 376 & Peak N & Microbial DOM from phytoplankton degradation or anthropogenic sources ${ }^{d}$ \\
\hline 4 & 275 & 330 & Peak T & Tryptophan-like FDOM; Amino acids, proteins \\
\hline
\end{tabular}

Primary and (secondary) excitation $\left(\lambda_{e x}\right)$ and emission $\left(\lambda_{e m}\right)$ maxima, compared with previously identified components. Superscript denotes reference citation: ${ }^{a}$ Coble et al., 1990 ; bStedmon and Markager, 2005; ${ }^{c}$ Cory and McKnight, 2005; ${ }^{d}$ e.g., wastewater effluent; Hosen et al., 2014.

September 2014 using a compact optical profiling system for UV light in natural waters (UV C-OPS; Biospherical Instruments Inc.) as previously described (Cory et al., 2013, 2014). The COPS measured downwelling cosine-corrected irradiance at seven wavebands $(305,313,320,340,380,395$, and $412 \mathrm{~nm})$ and PAR $(400-700 \mathrm{~nm})$. Attenuation coefficients $\left(K_{d, \lambda}\right)$ were calculated from the down-welling irradiance $\left(E_{\lambda}\right)$ as a function of depth $(z)$ at each waveband:

$$
E_{\lambda, z}=E_{\lambda, 0} e^{-K_{d, \lambda} z}
$$

From multiple casts, $(n=2-4)$, the coefficient of variation of $K_{d, \lambda}$ ranged from 1 to $3 \%$ in the UV and 9\% for PAR.

\section{Biological Activity}

Chlorophyll- $a$ concentration ( $\mathrm{Chl}$ a) was measured by concentrating lake water on a glass fiber filter (Whatman $\mathrm{GF} / \mathrm{F}, 47 \mathrm{~mm}$ diameter) using low vacuum pressure. Samples were extracted with $\mathrm{N}, \mathrm{N}$-dimethylformamide under low light levels and analyzed with a 10AU fluorometer (Turner Designs; Speziale et al., 1984). Particulate microcystins (MCs) were collected onto a $1.2 \mu \mathrm{m}$ polycarbonate membrane and kept at $-20^{\circ} \mathrm{C}$ until analysis. Particulate MCs were extracted from samples using a combination of physical and chemical lysis techniques. All samples were resuspended in $1 \mathrm{~mL}$ molecular grade water ( $\mathrm{pH} 7$; Sigma- Aldrich, St. Louis, MO) and subjected to three freeze/thaw cycles before the addition of the QuikLyse reagents (Abraxis LLC; Warminster, PA) as per the manufacturer' $s$ instructions. The samples were then centrifuged for $5 \mathrm{~min}$ at $2 \times 10^{3} \mathrm{~g}$ to pellet cellular debris. The concentrations of microcystins (reported as microcystin-LR equivalents) were measured using an enhanced sensitivity microcystin enzyme-linked immunosorbent assay (Abraxis LLC) following the methodologies of (Fischer et al., 2001). This assay is congener-independent as it detects the ADDA moiety, which is found in almost all MCs. These analyses yielded a detection limit of $0.04 \mu \mathrm{g} \mathrm{L}^{-1}$.

Whole water respiration was measured from unfiltered water at three of the six main stations collected weekly in the western basin in summer 2014. Each water sample was incubated for $3-5$ days in the dark at room temperature $\left(25^{\circ} \mathrm{C}\right.$, similar to summer lake temperature) alongside killed controls $\left(1 \% \mathrm{HgCl}_{2}\right)$ in air-tight, pre-combusted $12-\mathrm{mL}$ borosilicate exetainer vials (Labco, Inc). Respiration was measured as dissolved oxygen 
$\left(\mathrm{O}_{2}\right)$ consumption relative to killed controls using a membrane inlet mass spec (MIMS; Cory et al., 2014). There were four independent replicates from each water sample for every analysis type and treatment, and all values are presented as average \pm standard error.

\section{$\mathrm{H}_{2} \mathrm{O}_{2}$ Concentrations}

During the weekly sampling in the western basin in 2014, $0.2 \mu \mathrm{m}$ filtered water was prepared for $\mathrm{H}_{2} \mathrm{O}_{2}$ analysis below deck on the ship within $30 \mathrm{~min}$ of sample collection. In 2015, $0.2 \mu \mathrm{m}$ filtered water samples were transported on ice in the dark back to the laboratory for $\mathrm{H}_{2} \mathrm{O}_{2}$ analysis (hold time $2-8 \mathrm{~h}$ ). All samples collected onboard CCGS Limnos were immediately filtered through $0.2 \mu \mathrm{m}$ membrane filters and placed in the dark at $4^{\circ} \mathrm{C}$ until batches of 3-4 samples were ready for $\mathrm{H}_{2} \mathrm{O}_{2}$ analysis (hold time $<12 \mathrm{~h}$ ). $\mathrm{H}_{2} \mathrm{O}_{2}$ concentrations were measured using the Amplex Red method on a UPLC (Waters Technology Corporation) due to its sensitivity and selectivity for $\mathrm{H}_{2} \mathrm{O}_{2}$ (Burns et al., 2012). Standard additions of $\mathrm{H}_{2} \mathrm{O}_{2}(40-$ $500 \mathrm{nM}$ ) were performed on every sample with four replicates per concentration of added $\mathrm{H}_{2} \mathrm{O}_{2} \cdot \mathrm{H}_{2} \mathrm{O}_{2}$ concentrations were determined from the $x$-intercept and slope of the linear regression of the standard additions $\left(R^{2}\right.$ typically $\left.>0.98\right)$. Uncertainty in each $\mathrm{H}_{2} \mathrm{O}_{2}$ measurement was quantified as the standard error of the concentration, calculated from the variance in the $\mathrm{x}$-intercept of the standard addition. DI water, reagent blanks, and $\mathrm{H}_{2} \mathrm{O}_{2}$ check standards prepared in DI water were analyzed before, during, and after each cruise to identify contamination from "background" $\mathrm{H}_{2} \mathrm{O}_{2}$ present in the reagents and changes in $\mathrm{H}_{2} \mathrm{O}_{2}$ standards during the cruise. $\mathrm{H}_{2} \mathrm{O}_{2}$ in stock solutions used for the standard additions on the cruises generally decreased during the day by $\sim 5-10 \%$, and this decrease was taken into account for samples prepared in 2014 during the cruises.

\section{Photochemical Production of $\mathrm{H}_{2} \mathrm{O}_{2}$ by CDOM}

Photochemical production of $\mathrm{H}_{2} \mathrm{O}_{2}$ by $\mathrm{CDOM}$ in the water column over depth $\mathrm{z}$ is the product of three spectra: the apparent quantum yield (AQY) for $\mathrm{H}_{2} \mathrm{O}_{2}$ formation by CDOM ( $\Phi_{\lambda}$; mol $\mathrm{H}_{2} \mathrm{O}_{2}$ mol $^{-1}$ photons absorbed), the spectrum of the UV photon flux absorbed by $\operatorname{CDOM}\left(Q_{a, \lambda}\right.$; mol photons $\left.\mathrm{m}^{-2} \mathrm{~s}^{-1}\right)$, and the spectrum of the ratio of absorption by CDOM to the total absorption (i.e., $a_{\mathrm{CDOM}, \lambda} / a_{\mathrm{tot}, \lambda}$ ):

$$
\begin{gathered}
\mathrm{H}_{2} \mathrm{O}_{2} \text { production at depth } z\left(\text { mol } \mathrm{m}^{-3} \mathrm{~s}^{-1}\right) \\
=\frac{\int_{\lambda_{\min }}^{\lambda_{\max }} \phi_{\lambda} Q_{a \lambda} \frac{a C D O M_{\lambda}}{a t o t_{\lambda}} d \lambda}{z}
\end{gathered}
$$

Where $\lambda_{\min }$ and $\lambda_{\max }$ are the minimum and maximum wavelengths of light contributing to the photochemical formation of $\mathrm{H}_{2} \mathrm{O}_{2}$ by CDOM (280 and $420 \mathrm{~nm}$, respectively), $a_{\text {tot }}, \lambda$ is the total absorption in the water column (CDOM, particles, and water), and $Q_{a, \lambda}$ is the light absorbed by CDOM in the water column calculated as:

$$
Q_{a \lambda}\left(\text { mol photons } m^{-2} d^{-1}\right)=E_{o \lambda}\left(1-e^{-a_{C D O M, \lambda} z}\right)
$$

where $E_{0, \lambda}$ is the incident photon flux reaching the surface of Lake Erie. Here we provide information on how we quantified (a) the apparent quantum yield spectra $\left(\Phi_{\lambda}\right)$, (b) the photon flux spectra used to calculate photons absorbed by CDOM in the water column $\left(Q_{a, \lambda}\right)$, and (c) spectrum of the ratio of absorption by CDOM to the total absorption (i.e., $a_{\mathrm{CDOM}, \lambda} /$ $\left.a_{\mathrm{tot}, \lambda}\right)$. A spectrum of $a_{\mathrm{CDOM}, \lambda} / a_{\mathrm{tot}, \lambda}$ was obtained by dividing the absorption spectrum of CDOM by the absorption spectrum of whole water.

Several studies have reported little variation in the spectrum of the apparent quantum yield $\left(\Phi_{\lambda}\right)$ for $\mathrm{H}_{2} \mathrm{O}_{2}$ production from different sources of CDOM (Kieber et al., 2014; Powers and Miller, 2014), and thus average $\Phi_{\lambda}$, pooled from multiple marine and freshwaters measurements, are often used to estimate photochemical production of $\mathrm{H}_{2} \mathrm{O}_{2}$ by $\mathrm{CDOM}$ (Vermilyea et al., 2010; Powers and Miller, 2014). To evaluate whether use of a previously reported, pooled apparent quantum yield is realistic for Lake Erie, we compared calculated vs. observed photochemical $\mathrm{H}_{2} \mathrm{O}_{2}$ production rates from laboratory experiments where filtered Lake Erie water was exposed to simulated sunlight in borosilicate tubes using a Suntest XLS solar simulator (Atlas) alongside foil-wrapped dark controls. Water temperature ranged from 20 to $23^{\circ} \mathrm{C}$ over the 40 -min photoexposures. For Lake Erie water, the photo-exposure experiments fit the criteria for optically thin conditions, and thus can be characterized as near-surface photo-production rates:

$$
\begin{gathered}
\text { Near surface } \mathrm{H}_{2} \mathrm{O}_{2} \text { production }\left(\text { mol } \mathrm{m}^{-3} \mathrm{~s}^{-1}\right) \\
=\int_{\lambda_{\min }}^{\lambda_{\max }} \phi_{\lambda} E_{0 \lambda} a C D O M_{\lambda} d \lambda
\end{gathered}
$$

Where $E_{0, \lambda}$ is the incident light from the solar simulator reaching the water sample in the photo-tubes, corrected for transmission spectrum of the borosilicate glass (Cory et al., 2014). Exposure of river water and Lake Erie water collected in May 2014 resulted in production of $\mathrm{H}_{2} \mathrm{O}_{2}$ with no detectable dark loss of $\mathrm{H}_{2} \mathrm{O}_{2}$ from the filtered water over the experiment (Figure 3), consistent with biological decay as the main sink for $\mathrm{H}_{2} \mathrm{O}_{2}$ (Moffett and Zafiriou, 1990, 1993; Cooper et al., 1994). For each sample, the calculated photochemical production rate of $\mathrm{H}_{2} \mathrm{O}_{2}$ using previously reported $\Phi_{\lambda}$ was about three-fold lower than observed (at 310 or $350 \mathrm{~nm}$ ). Thus, we used an $\Phi_{\lambda}$ spectrum approximately three times the pooled mean value spectrum reported from Powers and Miller (2014) to generate estimates of photochemical production of $\mathrm{H}_{2} \mathrm{O}_{2}$ in Lake Erie; this results in a bias toward higher estimated rates of photochemical production (see Discussion).

To estimate the photon flux reaching the surface of Lake Erie $\left(E_{0, \lambda}\right)$, we used direct and indirect irradiance values corresponding to the time of the sample collection during each cruise (NCAR TUV calculator ${ }^{1}$ with latitude and longitude coordinates set at a station in the western basin of Lake Erie. This estimate of photon flux reaching the water surface of Lake Erie is likely a maximum, because it neglects the effects of clouds or reflection from the water surface.

\footnotetext{
$\overline{{ }^{1} \text { http://cprm.acom.ucar.edu/Models/TUV/Interactive_TUV/ }}$
} 

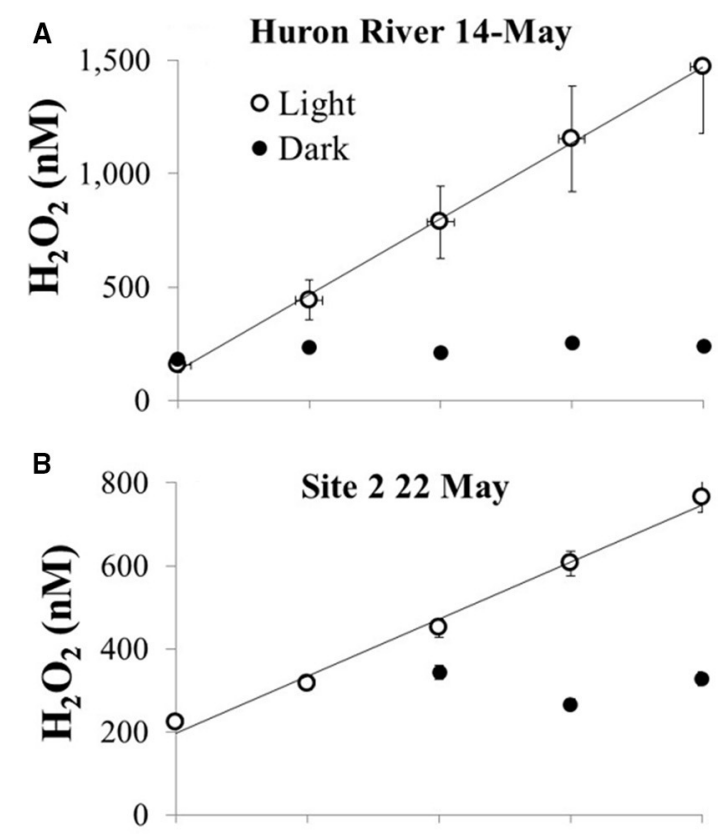

C

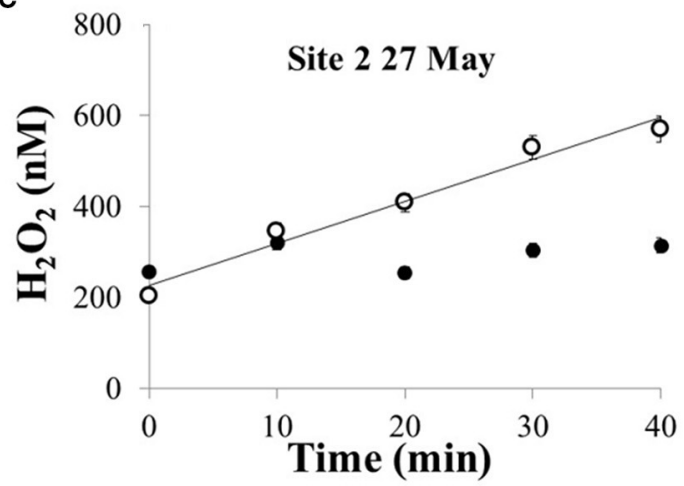

FIGURE 3 | Photochemical production of $\mathrm{H}_{2} \mathrm{O}_{2}$ from $0.2 \mu \mathrm{m}$ filtered water collected in May 2014 for (A) river that drains into Lake Erie, (B) Lake Erie site 2 collected on 22 May, and (C) Lake Erie site 2 collected on 27 May. All waters were exposed to simulated sunlight in the laboratory alongside foil-wrapped dark controls; water temperatures were between 20 and $23^{\circ} \mathrm{C}$ for light-exposed and dark samples.

\section{Biological Production and Decay of $\mathrm{H}_{2} \mathrm{O}_{2}$}

We estimated the net rate of biological production or decay of $\mathrm{H}_{2} \mathrm{O}_{2}$ in western Lake Erie from three microcosm experiments conducted during late August and early September 2014 onboard the CCGS Limnos. To initiate experiments, triplicate 2-L transparent, polycarbonate bottles were filled with whole surface water and either left unamended to serve as controls or spiked with nitrogen (ammonium nitrate; $20 \mu \mathrm{M}$ final concentration) and orthophosphate ( $2 \mu \mathrm{M}$ final concentration). Within an hour after sample collection, the experimental bottles were placed in flow-through incubators under natural light and temperature conditions for $48 \mathrm{~h}$ with nutrients replenished at $50 \%$ of initial spike concentrations every $12 \mathrm{~h}$. The incubators were covered in neutral density screen (Lee Filters) that reduced UV and visible light by $\sim 80-50 \%$ (as provided by the manufacturer, and checked in the laboratory using the diffuse reflectance accessory as described above for whole water absorbance measurements). Conducting experiments in visible light allowed the autotrophs to function while minimizing photochemical sources of $\mathrm{H}_{2} \mathrm{O}_{2}$, which depend on UV light (Andrews et al., 2000). Photochemical production of $\mathrm{H}_{2} \mathrm{O}_{2}$ by $\mathrm{CDOM}$ could range from $\sim 1 \mathrm{nM}$ $\mathrm{h}^{-1}$ to an upper limit of $36 \mathrm{nM} \mathrm{h}^{-1}$ during the microcosm experiments, with the most likely rate around $1-10 \mathrm{nM} \mathrm{h}^{-1}$. The values included in the calculation are well-constrained by measured values of CDOM in the water used in the microcosm experiments, by the transmission spectra of the filters used to screen the light, and by the apparent quantum yields of $\operatorname{CDOM}\left(\Phi_{\lambda}\right)$ in the literature. While visible light has been reported to account for some photochemical production of $\mathrm{H}_{2} \mathrm{O}_{2}$ in freshwaters (Richard et al., 2007), the CDOM absorption coefficients and AQYs are likely too low to result in substantial $\mathrm{H}_{2} \mathrm{O}_{2}$ during these experiments (see Results and Discussion), and thus photochemical formation of $\mathrm{H}_{2} \mathrm{O}_{2}$ by CDOM during the microcosm experiments was probably on the low end of the calculated production rates (i.e., $1-10 \mathrm{nM} \mathrm{h}^{-1}$ ). Thus, the design of the microcosm experiments isolated the biological contribution of $\mathrm{H}_{2} \mathrm{O}_{2}$ from photochemical sources of $\mathrm{H}_{2} \mathrm{O}_{2}$.

\section{RESULTS}

\section{Spatial and Temporal Patterns in CDOM Concentration}

CDOM absorption coefficients at $305 \mathrm{~nm}\left(a_{305}\right)$ ranged from 1 to $37 \mathrm{~m}^{-1}$ and were significantly, positively correlated with dissolved organic carbon (DOC) as expected (Figure 4). Thus, spatial and temporal patterns of CDOM represent concentrations of bulk DOC and of the light-absorbing fraction of the DOC pool. CDOM was significantly, positively correlated with specific conductivity (Figure 5A). Specific conductivity is a proxy for water masses associated with the Detroit or Maumee Rivers in the western basin of Lake Erie given that these rivers have different average conductivities and deliver substantial loads of total dissolved solids to the lake (Richards et al., 2010; Larson et al., 2013; Scavia et al., 2014). Because specific conductivity generally decreases with distance from the river mouths as water masses are mixed within the lake, the correlation between $a_{305}$ and specific conductivity also reflected the observation that CDOM increased with proximity to the rivers in both 2014 and 2015 (Figure 5).

Like the spatial gradients in CDOM in Lake Erie, year to year differences in CDOM also appeared to be related to river discharge. There was greater $\mathrm{CDOM}$ per unit specific conductivity in 2015 compared with 2014 (Figure 5A) concurrent with high Maumee River discharge associated with frequent storms in the region that led to the wettest June on record $^{2}$. During both summers in 2014 and 2015, CDOM was generally higher at each station in June compared with OctoberNovember (Figure 6), consistent with high river discharge from spring runoff or storms that increase specific conductivity and

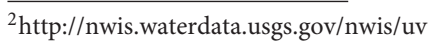




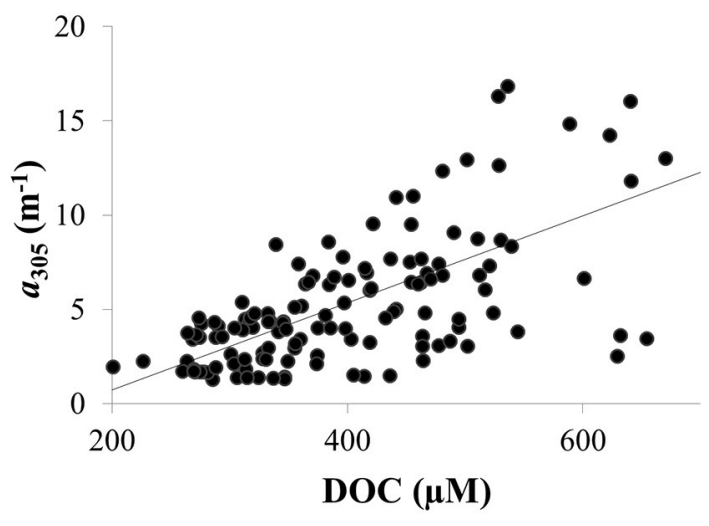

FIGURE 4 | CDOM concentration was positively correlated with DOC concentrations in Lake Erie in 2014 as shown for CDOM absorption coefficient at $305 \mathrm{~nm}\left(a_{305}\right)\left(R^{2}=\mathbf{0 . 4} ; \boldsymbol{p}<\mathbf{0 . 0 1}\right)$. Similar results were obtained using CDOM absorption coefficients at other wavelengths (not shown).

CDOM in the lake. The seasonal decrease in CDOM was greater in 2015 compared with 2014 (Figure 6A), and at stations closest to the river (data not shown).

\section{Spatial and Temporal Patterns in CDOM Source}

On average, CDOM in Lake Erie had low UV absorbance at $254 \mathrm{~nm}\left(\mathrm{SUVA}_{254}\right)$, high spectral slope ratio $\left(\mathrm{S}_{\mathrm{R}}\right)$, and a high fluorescence index (FI; Table 1). The values of these optical proxies for CDOM source (Tables 1, 2) demonstrated that CDOM has relatively low aromatic $\mathrm{C}$ content $\left(\mathrm{SUVA}_{254}\right.$ and FI; McKnight et al., 2001; Weishaar et al., 2003), and was comprised of relatively low molecular weight compounds ( $\mathrm{S}_{\mathrm{R}}$; Helms et al., 2008), consistent with a strong contribution of microbiallyderived organic matter to the CDOM pool in the lake (FI) (McKnight et al., 2001; Cory and McKnight, 2005).

Consistent with previous PARAFAC models of CDOM fluorescence (Table 2), the spectra of the CDOM components (Figure 2) suggested contributions from humic and fulvic acids associated with microbial $(\mathrm{C} 1)$ or terrestrial precursor organic matter (C2), CDOM from recently produced microbial matter (C3), and CDOM associated with free or combined amino acids (C4). Like CDOM absorption coefficients (e.g., $a_{305}$ ), the first three CDOM model components (C1, C2, C3; Table 2) were also significantly, positively correlated with specific conductivity $(p<0.01)$, providing further evidence for rivers as dominant sources of CDOM to the western basin of Lake Erie (shown for C2 in Figure 7A). Component C4 (amino-acid-like) was significantly, positively correlated with specific conductivity $(p<$ 0.01 ; Figure 7B), although the relationship was weaker compared with components $\mathrm{C} 1, \mathrm{C} 2$, and $\mathrm{C} 3$; this suggests relatively greater in-lake (autochthonous) sources of C4 compared with the other CDOM components.

There were spatial patterns in CDOM composition and source in Lake Erie. For example, the specific UV absorbance at $254 \mathrm{~nm}\left(\mathrm{SUVA}_{254}\right)$, a proxy for the aromatic C content

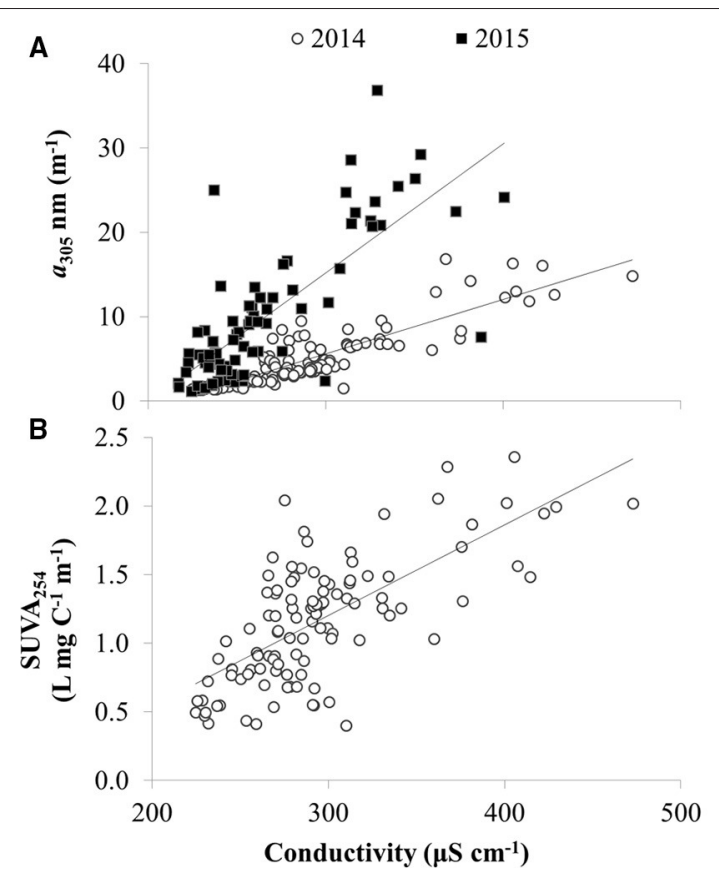

FIGURE 5 | CDOM concentration and composition vs. specific conductivity in Lake Erie. (A) CDOM absorption coefficient at $305 \mathrm{~nm}\left(a_{305}\right)$ vs. specific conductivity in 2014 and 2015. (B) Specific UV absorbance at $254 \mathrm{~nm}\left(\right.$ SUVA $\left._{254}\right)$ vs. conductivity in 2014 (DOC data not available for 2015). Lake water with higher specific conductivity is more influenced by river water, whereas lake water with lower specific conductivity is less influenced by river water. Lines show linear regression fit for slopes significantly different than zero $(p<0.01)$

of DOM, was significantly, positively correlated with specific conductivity (Figure 5B), indicating a decrease in aromatic $\mathrm{C}$ with distance from the river mouths in western Lake Erie. Likewise, the ratio of amino-acid to terrestrial humic CDOM (C4/C2) was significantly, inversely correlated with specific conductivity (Figure 7C), consistent with a shift in CDOM source to relatively more autochthonous organic matter offshore compared with stations closest to the rivers.

In contrast to the spatial patterns in surface waters of Lake Erie, there was little difference in CDOM amount or composition with depth for the deeper sites sampled on the Limnos cruises. For example, the amount of terrestrial humic component $\mathrm{C} 2$ in surface vs. bottom waters was similar under mixed conditions (i.e., surface vs. bottom values of $\mathrm{C} 2$ plotted on the 1:1 line in Figure 8A), and only slightly higher $\mathrm{C} 2$ was observed in surface vs. bottom waters under stratified conditions (Figure 8A). Surface waters were slightly enriched compared to bottom waters in amino-acid component $\mathrm{C} 4$ compared with terrestrial component $\mathrm{C} 2$ under both stratified and mixed conditions (Figure 8B), suggesting more autochthonous production of amino-acid like FDOM in surface than in bottom waters.

There were seasonal shifts in CDOM source. At most stations, the ratio of amino-acid to terrestrial humic components (C4/C2) increased from June through October in both 2014 and 2015 (Figure 6B), demonstrating a relative increase in autochthonous 


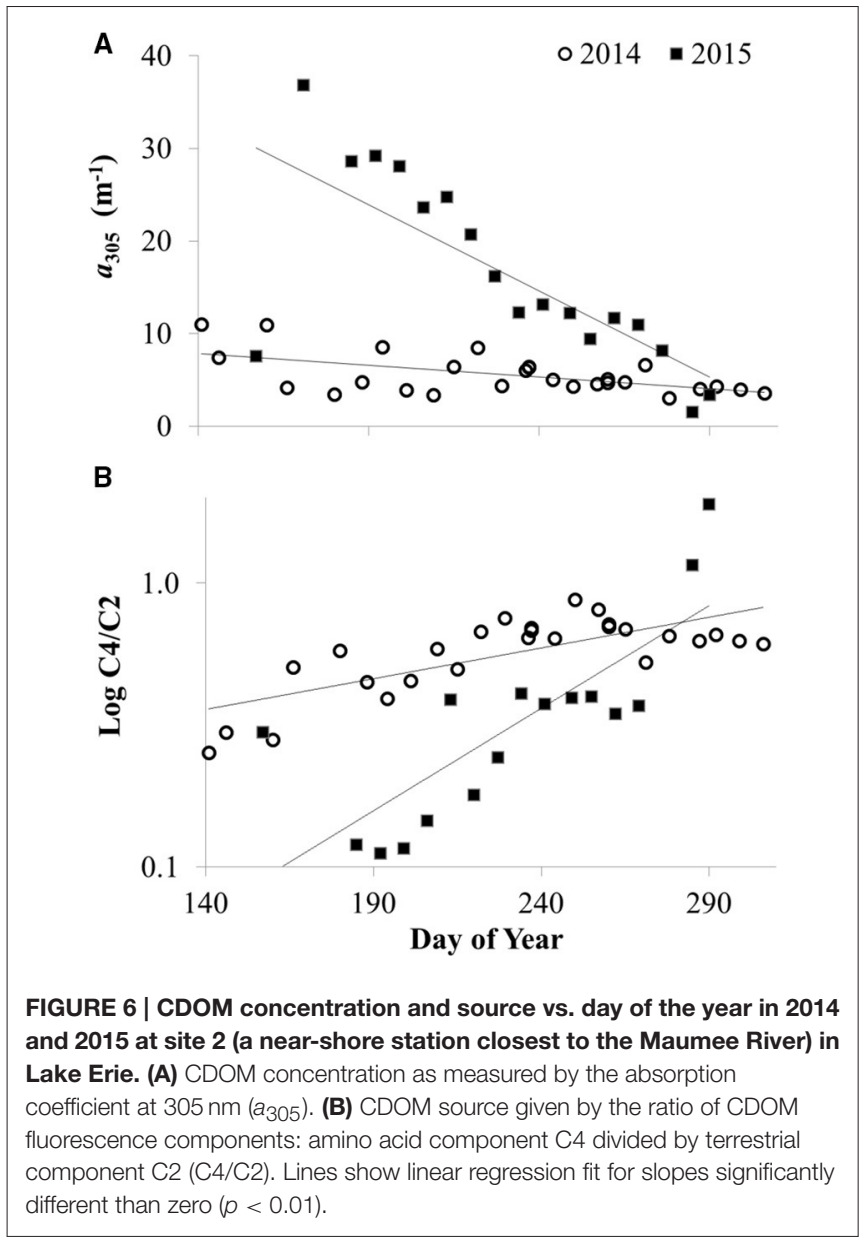

sources of CDOM over the summer. The increase in $\mathrm{C} 4 / \mathrm{C} 2$ over the summer was greater in 2015 compared with 2014 (Figure 6B). Although CDOM shifted in a manner consistent with greater autochthonous inputs over the course of the bloom in Lake Erie during both 2014 and 2015, there were no significant correlations between CDOM concentration or composition and indicators of bloom strength or toxicity (i.e., Chl $a$, whole water respiration, or particulate microcystins).

\section{Light Absorption and Attenuation}

The fraction of UV light absorbed by CDOM relative to all $\mathrm{UV}$-absorbing constituents in the water column (i.e., $a_{\mathrm{CDOM} \lambda}$ $\left./ a_{\text {tot } \lambda}\right)$ ranged from $0.72 \pm 0.02$ at $305 \mathrm{~nm}$ to $0.67 \pm 0.02$ at $412 \mathrm{~nm}(n=64$; Figure 9). This result shows that CDOM accounted for $\sim 70 \%$ of the UV light absorbed in the water column of Lake Erie. Similar results were obtained by comparing the absorbance coefficients of $\operatorname{CDOM}\left(a_{\mathrm{CDOM}} \lambda\right.$, measured on filtered water in the laboratory), to the attenuation coefficients measured in-situ in Lake Erie $\left(K_{d, \lambda}\right.$, corrected for solar zenith angle at the time of collection in the field). For a smaller dataset ( $n=9$ comparisons) than the $a_{\mathrm{CDOM} \lambda} / a_{\mathrm{tot} \lambda}$ ratios, $a_{\mathrm{CDOM} \lambda}$ values were on average $60 \pm 10 \%$ to $40 \pm 10 \%$ of the $K_{d, \lambda}$ value for the same water at $305-412 \mathrm{~nm}$, respectively
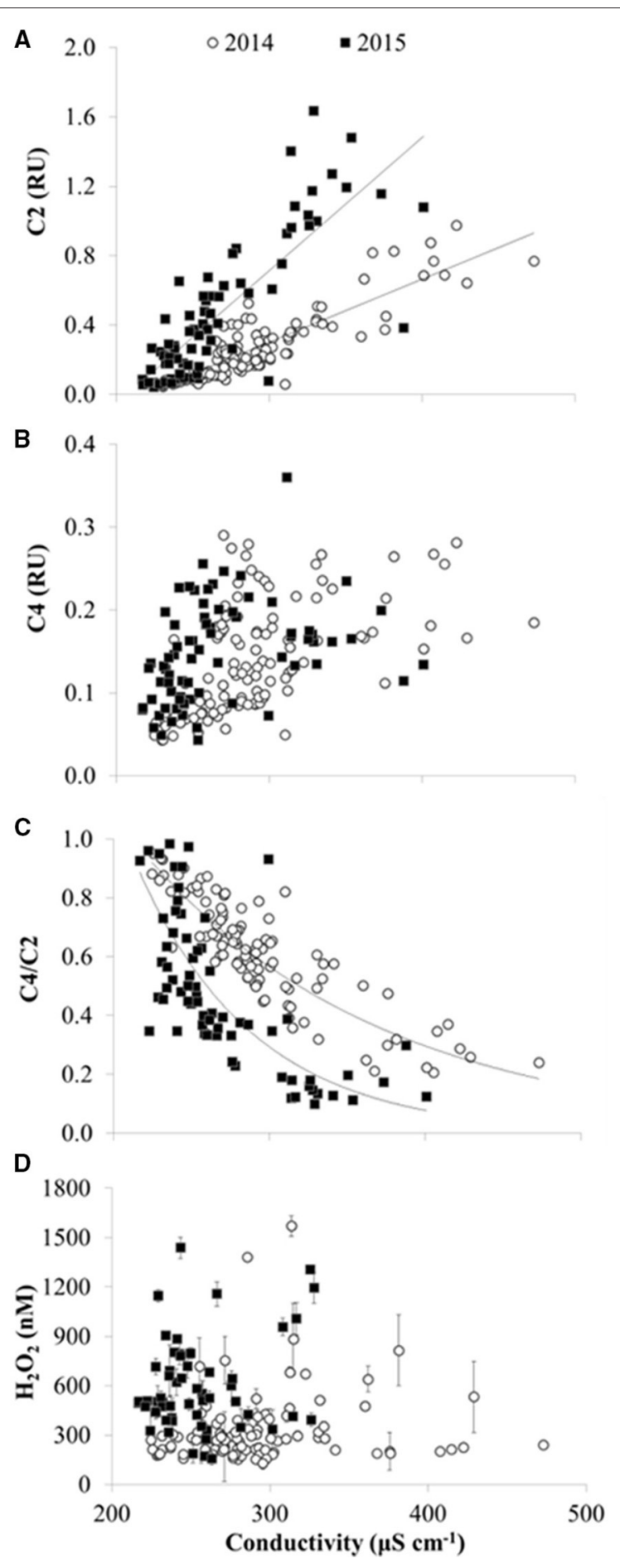

FIGURE 7 | CDOM fluorescence and $\mathrm{H}_{2} \mathrm{O}_{2}$ vs. specific conductivity in 2014 and 2015 in Lake Erie. (A) Concentration of CDOM fluorescence component C2 (terrestrial humic-like FDOM) in Raman Units (RU). Lines show fit of linear regressions for slopes significantly different than zero at $p<0.01$. (B) Concentration of CDOM component C4 (amino acid-like FDOM). While the slope of C4 vs. specific conductivity was significantly different than zero ( $p<0.05$ ) for 2014 and 2015, results of the linear regression were not plotted due to $R^{2}<0.3$. (C) CDOM source given by the ratio of amino acid component C4 divided by terrestrial component C2 (C4/C2). Lines show exponential fit. (D) $\mathrm{H}_{2} \mathrm{O}_{2}$ concentrations (average $\pm \mathrm{SE}, n=4$ ). 


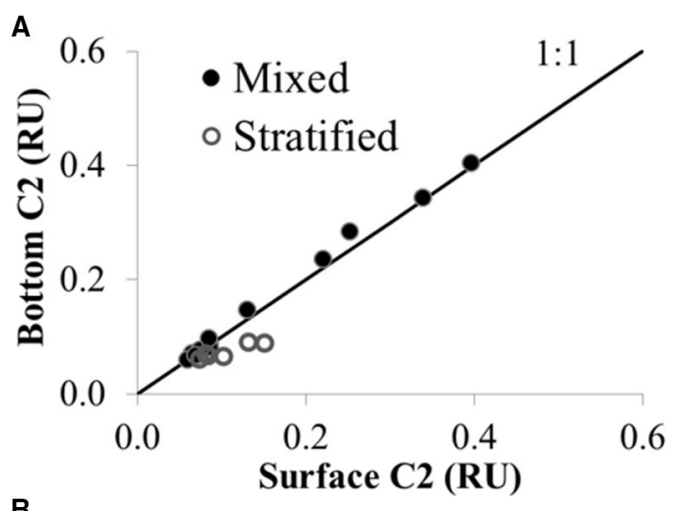

B

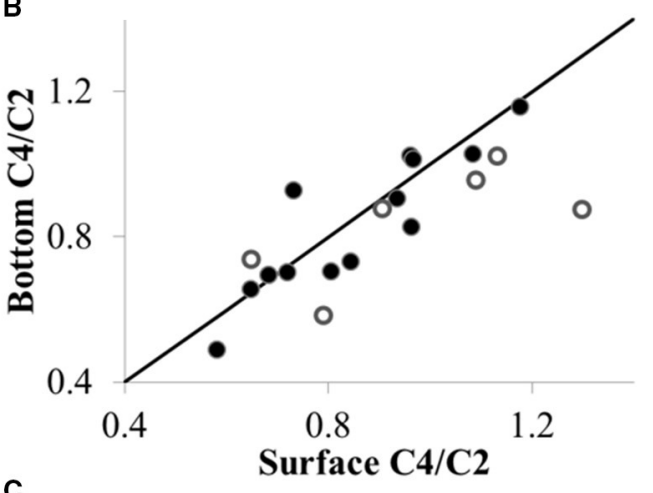

C

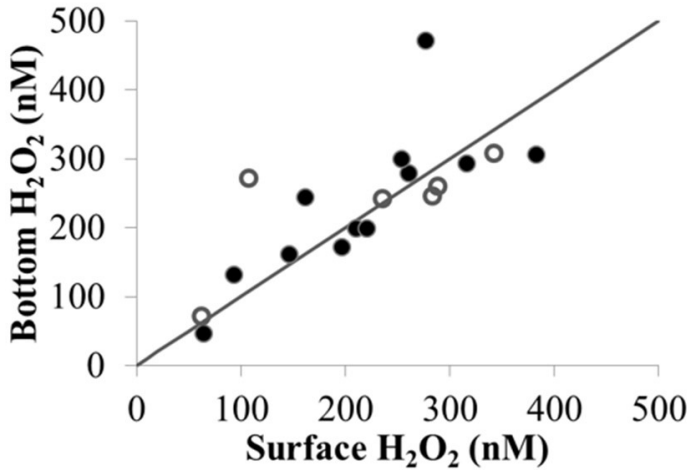

FIGURE 8 | CDOM fluorescence and $\mathrm{H}_{2} \mathrm{O}_{2}$ in surface (upper $1 \mathrm{~m}$ ) vs. bottom waters (4-61 $\mathrm{m}$ ) under mixed and stratified conditions in Lake Erie plotted with the 1:1 line. (A) Concentration of CDOM component $C 2$ (terrestrial humic-like FDOM) in Raman Units (RU). (B) Ratio of amino acid to terrestrial $\mathrm{CDOM}$ (C4/C2). (C) $\mathrm{H}_{2} \mathrm{O}_{2}$ concentration (nM). Sites sampled with depths $>7 \mathrm{~m}$ were those sampled in the central and eastern basin of Lake Erie on the Limnos cruises (see Figure 1).

(data not shown). Thus, independent of the approach used to characterize the fraction of UV light absorbed by CDOM in the water column, the results showed that CDOM accounted for $60-70 \%$ of UV absorbance in the water column of Lake Erie.

However, there were some spatial and temporal differences in the fraction of total UV light absorbed by CDOM in Lake Erie. Maximum ratios of $a_{\mathrm{CDOM} \lambda} / a_{\mathrm{tot} \lambda}(\sim 1)$ were most often observed at the most offshore stations (sites 4 and13; Figure 1), indicating that at these stations CDOM was the dominant UV light absorbing constituent in the water column with little

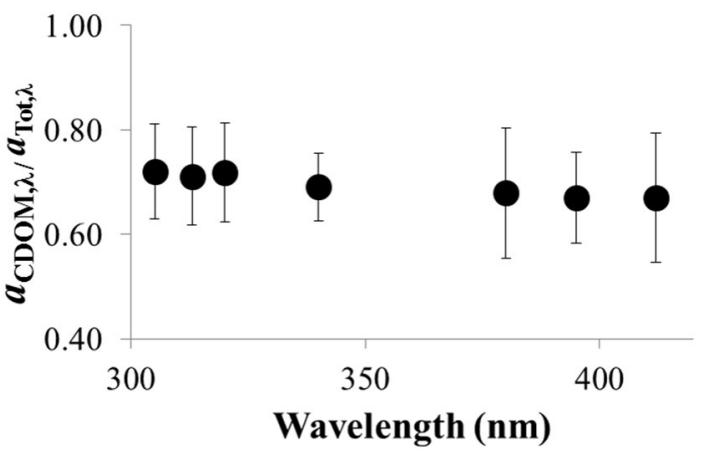

FIGURE 9 | Ratio of of $a_{\mathrm{CDOM}, \lambda} / a_{\mathrm{Tot}, \lambda}$ vs. wavelength in the UV for Lake Erie water (average $\pm \mathrm{SE}, \boldsymbol{n}=64$ water samples collected over the summer in 2014).

contribution from algae or other particles. The lowest ratio of $a_{\mathrm{CDOM} \lambda} / a_{\text {tot } \lambda}(0.14 \pm 0.02$ at $412 \mathrm{~nm})$ was observed when the water was turbid likely from resuspension of bottom sediments following a storm in November 2014.

\section{$\mathrm{H}_{2} \mathrm{O}_{2}$ Concentrations in Lake Erie}

$\mathrm{H}_{2} \mathrm{O}_{2}$ concentrations in the surface waters of Lake Erie varied by over an order of magnitude during the study period, from $47 \pm 16 \mathrm{nM}$ to $1570 \pm 60 \mathrm{nM}$ (average \pm SE from triplicate measurements of each water sample), with an overall average of $371 \pm 17 \mathrm{nM}$ (average $\pm \mathrm{SE}, n=225$; Figure 10D). $\mathrm{H}_{2} \mathrm{O}_{2}$ concentrations were not correlated with any chemical or physical parameter in Lake Erie (e.g., DOC, CDOM concentration or sources, date, time, water temperature, PAR, $\mathrm{pH}$, specific conductivity, wave height, or any other parameter measured concurrently with $\mathrm{H}_{2} \mathrm{O}_{2}$ concentrations; data not shown).

Temporal patterns of variation in $\mathrm{H}_{2} \mathrm{O}_{2}$ concentrations were generally larger than spatial variation in $\mathrm{H}_{2} \mathrm{O}_{2}$ in the lake. In both 2014 and 2015, maximum $\mathrm{H}_{2} \mathrm{O}_{2}$ concentrations were observed at all stations in mid to late July, just prior to peak $\mathrm{Chl} a$, whole water respiration rates, and particulate microcystins at all stations (Figure 10). In addition, fairly similar concentrations of $\mathrm{H}_{2} \mathrm{O}_{2}$ were observed between stations on a given date except when $\mathrm{H}_{2} \mathrm{O}_{2}$ concentrations were highest (Figure 11). For example, comparing $\mathrm{H}_{2} \mathrm{O}_{2}$ at the station closest to the river with the most offshore station, usually there was no detectable difference in $\mathrm{H}_{2} \mathrm{O}_{2}$ between stations (Figure 11) despite large differences in water chemistry or biology. In contrast, there were large differences in $\mathrm{H}_{2} \mathrm{O}_{2}$ concentrations between the near-river and offshore stations when $\mathrm{H}_{2} \mathrm{O}_{2}$ concentrations peaked in mid to late July 2014 (Figure 11)

$\mathrm{H}_{2} \mathrm{O}_{2}$ concentrations were generally similar between surface and bottom waters, despite a wide range in water depth (from 4 to $61 \mathrm{~m}$, depending on the site sampled) and degree of stratification at the time of sample collection at each station (Figure 8C). The largest difference in $\mathrm{H}_{2} \mathrm{O}_{2}$ concentration between surface water and depth was observed when $\mathrm{H}_{2} \mathrm{O}_{2}$ at $21 \mathrm{~m}$ was nearly double the surface concentration at the same site under 
A

$$
\text { A }
$$
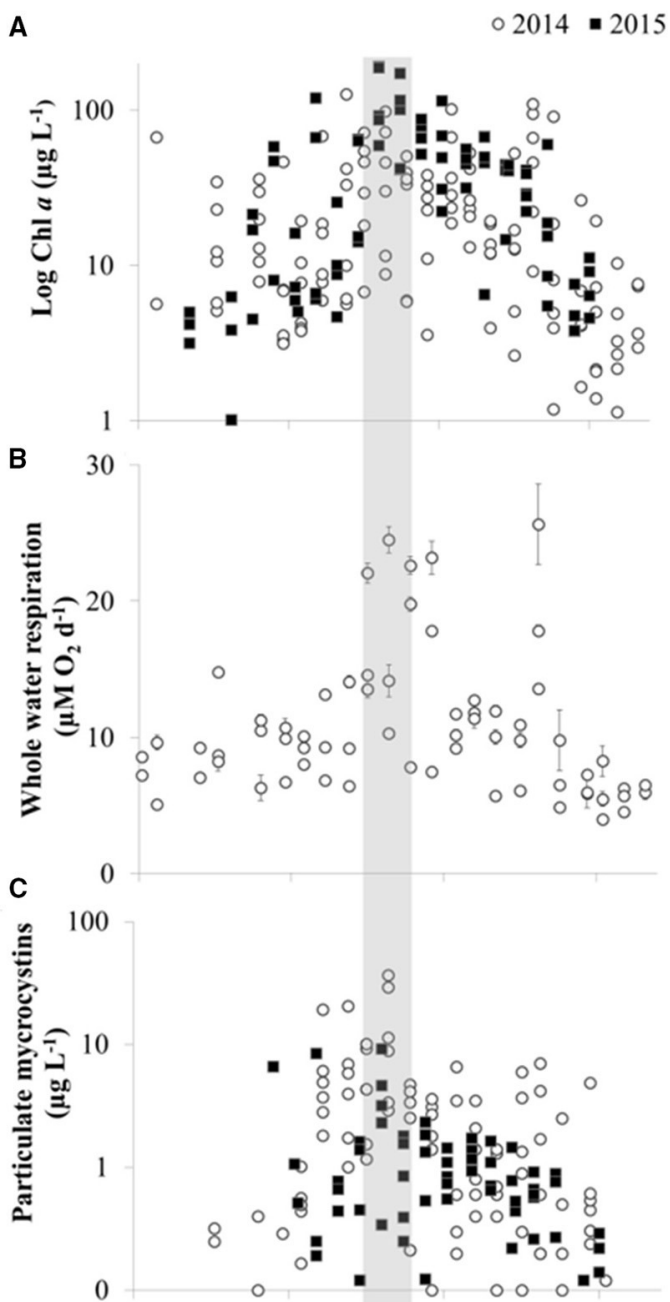

D 2000

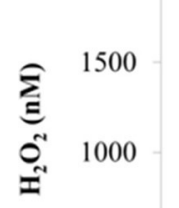

500

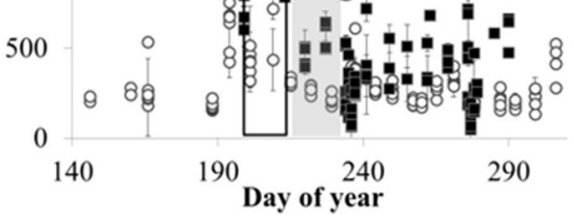

FIGURE 10 | Temporal patterns in biological activity and $\mathrm{H}_{2} \mathrm{O}_{2}$ in Lake Erie. (A) Chlorophyll a (Chl a) concentrations. (B) Whole water respiration rates (average $\pm \mathrm{SE}, n=3$ ). (C) Concentration of particulate microcystins. (D) $\mathrm{H}_{2} \mathrm{O}_{2}$ concentrations (average $\pm \mathrm{SE}, n=4$ ). The shaded bar indicates the time of peak $\mathrm{Chl} a$, whole water respiration, and particulate microcystins, while the open bar indicates the earlier peak in $\mathrm{H}_{2} \mathrm{O}_{2}$ concentrations.

mixed conditions $\left(471 \pm 65 \mathrm{nM}\right.$ vs. $277 \pm 49 \mathrm{nM} \mathrm{H}_{2} \mathrm{O}_{2}$ in bottom vs. surface, respectively at site 949 in the central basin; Figure 8C).

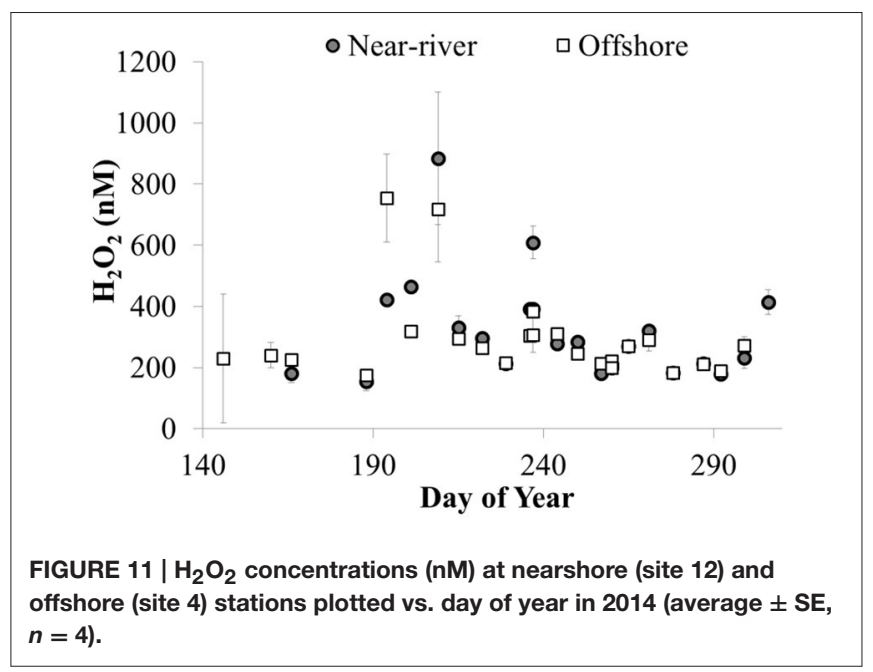

\section{Calculated Photochemical Production of $\mathrm{H}_{2} \mathrm{O}_{2}$ by CDOM}

UV light reaching the lake surface and CDOM concentrations peaked in June and then decreased over the summer season (Figure 12A). It follows that the calculated photochemical production of $\mathrm{H}_{2} \mathrm{O}_{2}$ in the water column by CDOM decreased from $\sim 150 \mathrm{nM} \mathrm{h}^{-1}$ in waters with high light and high CDOM in May and June to $<10 \mathrm{nM} \mathrm{h}^{-1}$ in waters with low light and low CDOM in October [assuming a constant apparent quantum yield for $\mathrm{H}_{2} \mathrm{O}_{2}$ production from CDOM; Equation (3)].

\section{Biological Production of $\mathrm{H}_{2} \mathrm{O}_{2}$}

There was a net increase in $\mathrm{H}_{2} \mathrm{O}_{2}$ production during the day (from $\sim$ 09:00 $\mathrm{h}$ through 17:00 $\mathrm{h}$ ) in the microcosm experiments conducted with Lake Erie waters, followed by little to no change in $\mathrm{H}_{2} \mathrm{O}_{2}$ concentrations overnight (Figure 13). Interpreting the increase in $\mathrm{H}_{2} \mathrm{O}_{2}$ concentrations over the first $8 \mathrm{~h}$ of the experiments as an estimate of the net rate of biological production (i.e., assuming both production and decay of $\mathrm{H}_{2} \mathrm{O}_{2}$ are occurring in the microcosms), then the net rate of biological production of $\mathrm{H}_{2} \mathrm{O}_{2}$ was $30 \pm 14 \mathrm{nM} \mathrm{h}^{-1}$ (Figure 13). While addition of $N$ and $P$ had no statistically significant effect on the net rate of biological production of $\mathrm{H}_{2} \mathrm{O}_{2}$ compared to controls with no added nutrients ( $36 \pm 17 \mathrm{nM} \mathrm{h}^{-1}$; Figure 13), addition of these nutrients did increase algal production as indicated by significantly higher $\mathrm{Chl} a$ concentrations at the end of the experiment $(48 \mathrm{~h})$ compared to the un-amended waters (Figure 14).

\section{DISCUSSION}

The average and range of $\mathrm{H}_{2} \mathrm{O}_{2}$ ) concentrations in Lake Erie ( $371 \pm 17 \mathrm{nM}$, range $47-1570 \mathrm{nM}$; Table 1 and Figure 10D) were higher than the range previously observed at one station in the western basin of Lake Erie in August 1987 (100-200 nM; Cooper et al., 1989), but within the wide range of $\mathrm{H}_{2} \mathrm{O}_{2}$ concentrations observed in lakes $(\sim 10 \mathrm{nM}$ to $>2 \mu \mathrm{M}$; Cooper and Zika, 1983; Cooper et al., 1989; Scully et al., 1996; Häkkinen 


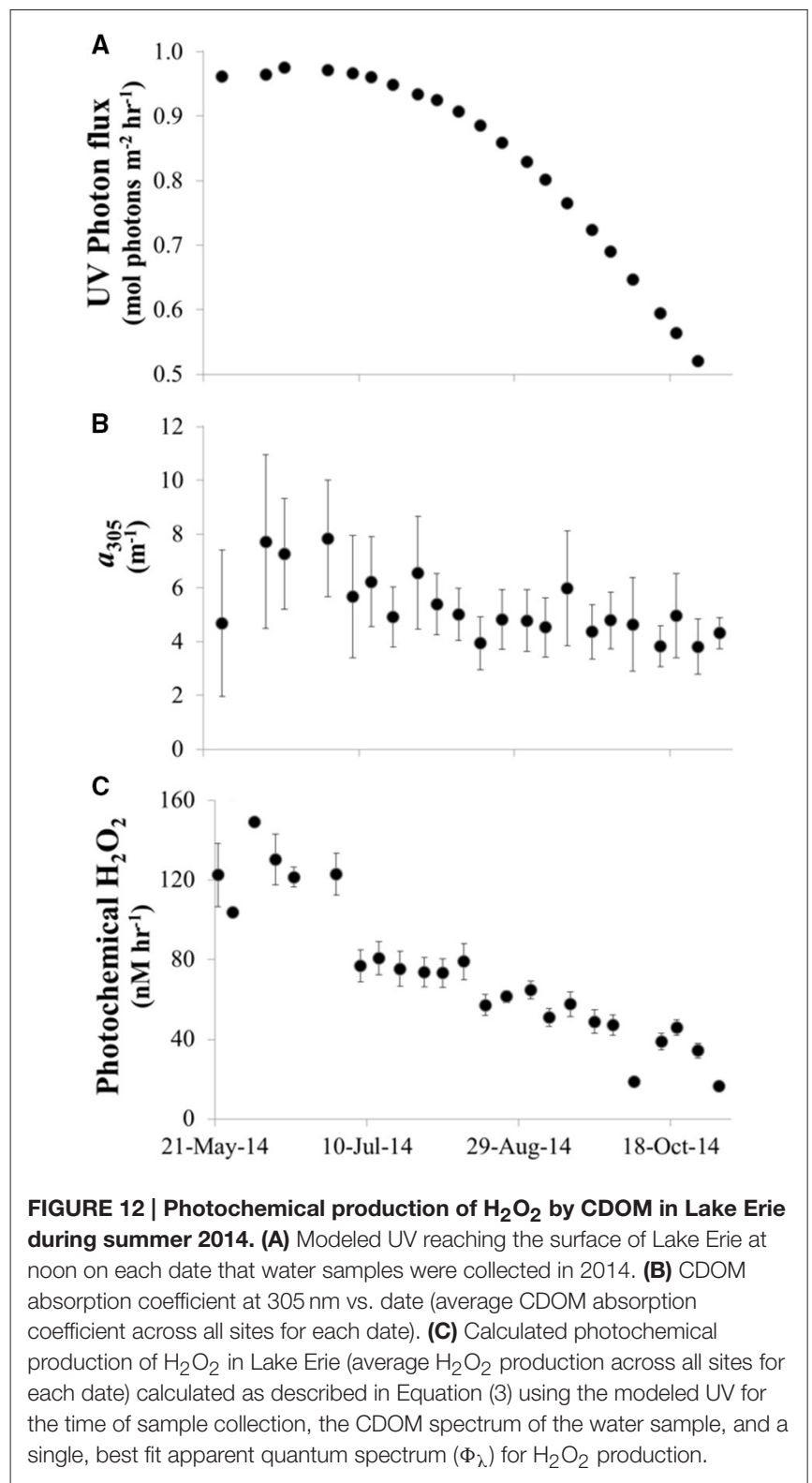

et al., 2004; Febria et al., 2006; Mostofa et al., 2013). Although no studies have measured $\mathrm{H}_{2} \mathrm{O}_{2}$ concentrations in freshwaters with the same degree of spatial and temporal resolution and alongside supporting chemical and biological characterization as in this study, a similar range of $\mathrm{H}_{2} \mathrm{O}_{2}$ concentrations has been reported in a small, urban stream in New Zealand where daily measurements over one year showed $\mathrm{H}_{2} \mathrm{O}_{2}$ concentrations ranged from $\sim 70 \mathrm{nM}$ in winter to nearly $700 \mathrm{nM}$ in summer (Rusak et al., 2005). The large range of $\mathrm{H}_{2} \mathrm{O}_{2}$ concentrations observed in Lake Erie spans the range of $\mathrm{H}_{2} \mathrm{O}_{2}$ concentrations shown to strongly impact microbial physiology in controlled laboratory experiments (Dziallas and Grossart, 2011; Zilliges et al., 2011; Leunert et al., 2014), or to result from microbial activity in eutrophic waters (Dixon et al., 2013; Marsico et al., 2015). Here, we present three lines of evidence in support of

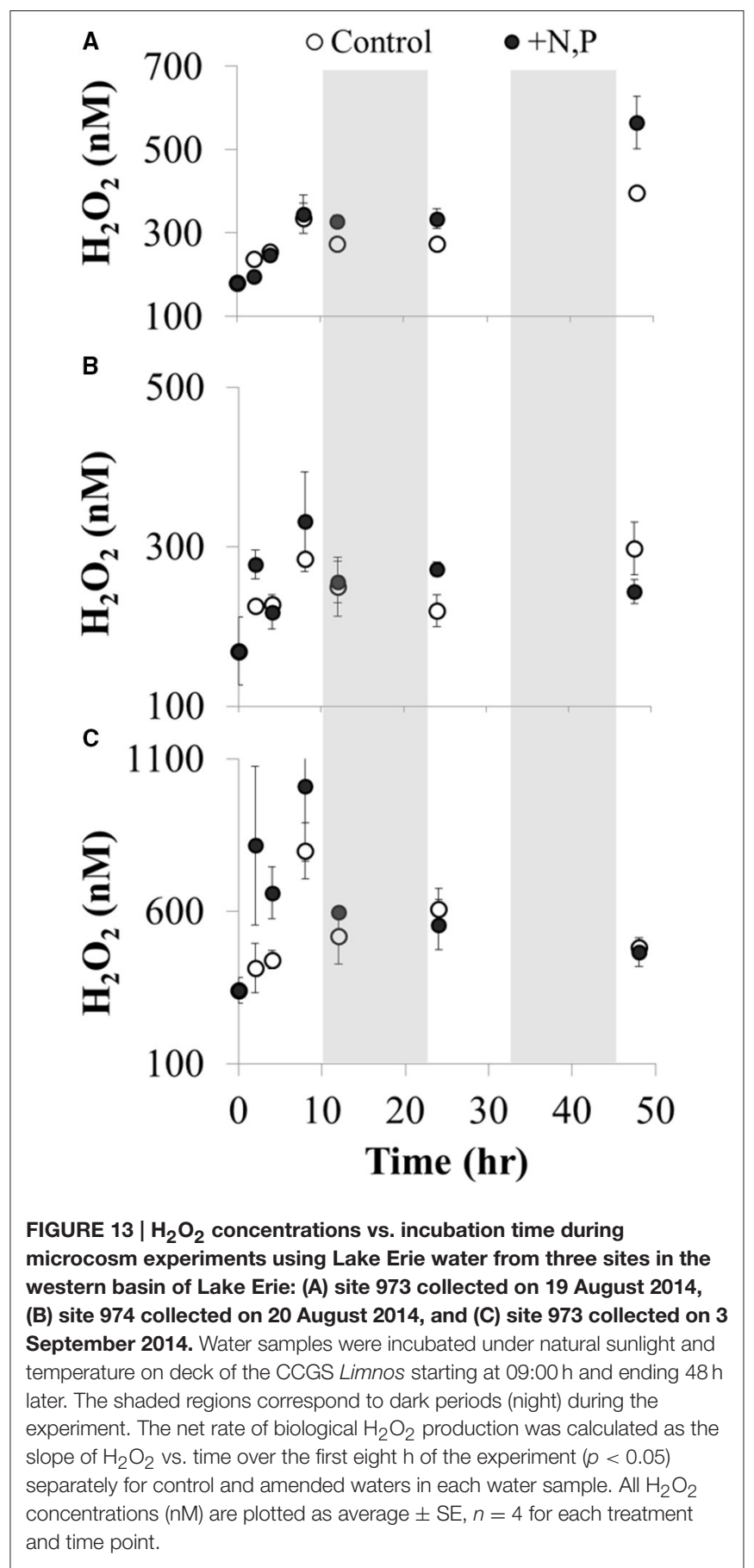

biological activity rather than photochemical production as the dominant source and control on $\mathrm{H}_{2} \mathrm{O}_{2}$ dynamics in Lake Erie.

First, photochemical production rates of $\mathrm{H}_{2} \mathrm{O}_{2}$ were likely too low to account for all $\mathrm{H}_{2} \mathrm{O}_{2}$ observed in Lake Erie. Using the average calculated photochemical production rate of $67 \pm$ $3 \mathrm{nM} \mathrm{h}^{-1} \mathrm{H}_{2} \mathrm{O}_{2}$ by CDOM, it would take about $5 \mathrm{~h}$ of mid-day light to produce the observed average concentration of $\mathrm{H}_{2} \mathrm{O}_{2}$ $(371 \pm 17 \mathrm{nM})$ assuming no other sources and no sinks. All water samples were collected between 0900 and $1530 \mathrm{~h}$, with 


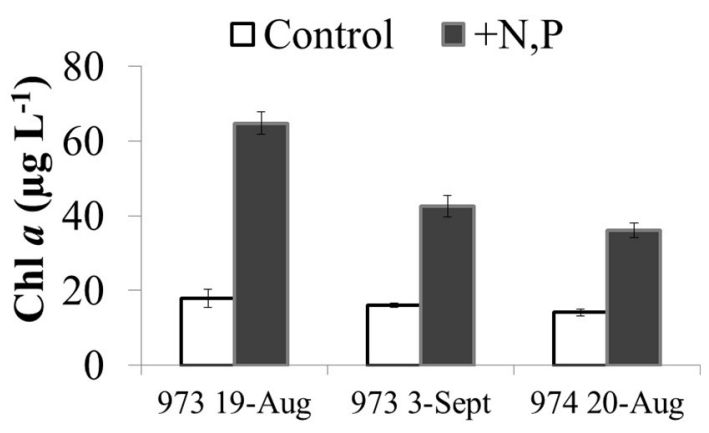

FIGURE 14 | Chlorophyll a concentrations at the end of the microcosm experiments $(t=48 \mathrm{~h})$ using Lake Erie water from the western basin (sites 973 and 974) in August and September 2014. Chlorophyll $a$ in control (unamended lake water) is compared to the same water amended with $\mathrm{N}$ and $\mathrm{P}$.

the majority of samples collected between 1000 and $1230 \mathrm{~h}$, meaning that that there was often insufficient time and UV light for photochemical production to generate the observed concentrations, even in the absence of $\mathrm{H}_{2} \mathrm{O}_{2}$ sinks. The calculated photochemical production rates of $\mathrm{H}_{2} \mathrm{O}_{2}$ by CDOM in Lake Erie agreed very well with calculated rates in Lake Ontario (for similar days of the year and CDOM values; Jerome and Bukata, 1998) and overlapped with the range reported for photochemical production rates in higher latitude coastal waters (e.g., 20$45 \mathrm{nM} \mathrm{h}^{-1}$; Vermilyea et al., 2010). Calculated photochemical production rates of $\mathrm{H}_{2} \mathrm{O}_{2}$ by CDOM in this study and previous studies were likely upper estimates given that rates were not corrected for actual cloud cover or reflection of UV light off the water surface, both of which would decrease the UV light available and thus decrease the photochemical production of $\mathrm{H}_{2} \mathrm{O}_{2}$.

Photochemical production of $\mathrm{H}_{2} \mathrm{O}_{2}$ by CDOM could account for most of the observed $\mathrm{H}_{2} \mathrm{O}_{2}$ if CDOM in the lake consistently had $\sim 3$-fold higher apparent quantum yields $\left[\Phi_{\lambda}\right.$; Equation (3)] than we used. This is because photochemical production rates of $\mathrm{H}_{2} \mathrm{O}_{2}$ increase linearly with increasing $\Phi_{\lambda}$ (Equation $3)$. However, to generate an upper estimate for $\mathrm{H}_{2} \mathrm{O}_{2}$ from CDOM, we used an $\Phi_{\lambda}$ spectrum that was already $\sim 3$-fold higher (at $305 \mathrm{~nm}$, see Section Photochemical Production of $\mathrm{H}_{2} \mathrm{O}_{2}$ by $\mathrm{CDOM}$ above) than the pooled mean spectra in recent literature syntheses (Kieber et al., 2014; Powers and Miller, 2014), because this $\Phi_{\lambda}$ spectrum accommodated the experimental photochemical production rate of $\mathrm{H}_{2} \mathrm{O}_{2}$ measured from laboratory irradiations of Lake Erie water collected in May 2014.

While variation in $\Phi_{\lambda}$ may be expected in space and time in Lake Erie given the shifts in CDOM source and thus composition (Figures 6, 7), the $\Phi_{\lambda}$ spectrum we used was likely on the high end expected from CDOM across all stations and dates in Lake Erie. In May when photochemical production of $\mathrm{H}_{2} \mathrm{O}_{2}$ was quantified from Lake Erie water samples, CDOM was more strongly terrestrially derived compared with CDOM in mid to late summer (Figure 6), and slightly higher $\Phi_{\lambda}$ spectra for $\mathrm{H}_{2} \mathrm{O}_{2}$ have been reported in freshwaters where CDOM is predominately terrestrially-derived compared with more autochthonous sources of CDOM predominately investigated in marine waters (Cooper et al., 1989; Scully et al., 1996; Andrews et al., 2000; O’Sullivan et al., 2005). Furthermore, recent syntheses of the literature reported a fairly narrow range of $\Phi_{\lambda}$ spectra and $\mathrm{H}_{2} \mathrm{O}_{2}$ photo-production from waters containing diverse sources of CDOM in seawater (Kieber et al., 2014; Powers and Miller, 2014). This narrow range of $\Phi_{\lambda}$ spectra is consistent with similar photochemical production rates of $\mathrm{H}_{2} \mathrm{O}_{2}$ from endmember sources of aquatic DOM (Cory et al., 2010a). Thus, we expect that $\Phi_{\lambda}$ spectra for $\mathrm{H}_{2} \mathrm{O}_{2}$ also spanned a relatively narrow range in Lake Erie, and that shifts in CDOM source to more autochthonous over the summer or with distance away from the river mouths most likely decreased $\Phi_{\lambda}$ for photochemical production of $\mathrm{H}_{2} \mathrm{O}_{2}$ from CDOM.

Photochemical production of $\mathrm{H}_{2} \mathrm{O}_{2}$ by CDOM may also have been higher than we calculated if the $\Phi_{\lambda}$ spectrum was relatively flat or only weakly exponential from the UV to visible wavelengths, instead of decreasing exponentially with wavelength as shown in all prior work on CDOM (Cooper et al., 1988; Scully et al., 1996; Andrews et al., 2000; Yocis et al., 2000; Kieber et al., 2014). Higher $\Phi_{\lambda}$ of $\mathrm{H}_{2} \mathrm{O}_{2}$ in the visible (i.e., $>420 \mathrm{~nm}$ ) would substantially increase photochemical $\mathrm{H}_{2} \mathrm{O}_{2}$ because there is more visible than UV irradiance reaching the water surface. Given the mean CDOM absorption coefficients at $412 \mathrm{~nm}\left(1.1 \pm 0.1 \mathrm{~m}^{-1}\right)$ for visible light (PAR) to account for the $\mathrm{H}_{2} \mathrm{O}_{2}$ formation in Lake Erie, the $\Phi_{\lambda}$ spectrum would have to be relatively high $\left(\sim 1 \mathrm{mmol} \mathrm{H}_{2} \mathrm{O}_{2} \mathrm{~mol}^{-1}\right.$ photons $\mathrm{nm}^{-1}$ ) and flat (wavelength independent). There is no evidence in the literature for higher $\Phi_{\lambda}$ for $\mathrm{H}_{2} \mathrm{O}_{2}$ in the visible compared to UV for CDOM, and in fact all studies that have measured wavelength-dependent $\Phi_{\lambda}$ from CDOM show that the spectrum decreases exponentially with increasing wavelength from UV to visible for CDOM in fresh and marine waters (Scully et al., 1996; Andrews et al., 2000; Yocis et al., 2000).

The second line of evidence for predominately biological control is that $\mathrm{H}_{2} \mathrm{O}_{2}$ concentrations were decoupled from CDOM source or amount (Figure 7). CDOM was the dominant UV-light absorbing constituent in the water column even during peak algal activity in the lake (Figure 9), and over the range of CDOM absorption coefficients in Lake Erie, increasing UV and CDOM increased photochemical production of $\mathrm{H}_{2} \mathrm{O}_{2}$ in the water column [Equation (3); Figure 12]. However, there was no correlation between calculated photochemical production of $\mathrm{H}_{2} \mathrm{O}_{2}$ and $\mathrm{H}_{2} \mathrm{O}_{2}$ concentrations, or between $\mathrm{H}_{2} \mathrm{O}_{2}$ concentrations and any proxy for the high light or high CDOM conditions that favor photochemical production by CDOM (i.e., CDOM, PAR, date, or sample collection time).

Furthermore, $\mathrm{H}_{2} \mathrm{O}_{2}$ concentrations were not higher in surface waters compared to bottom waters, as would be expected if photochemistry controlled $\mathrm{H}_{2} \mathrm{O}_{2}$ concentrations (Figure 8C). In addition, bottom water concentrations were too high to have been produced by the light and CDOM available. For example, given that the depths of bottom water sampled (4-61 m) were also greater than the depth of UV light penetration (depth of 1\% light was $1.5 \mathrm{~m} \pm 0.1 \mathrm{~m}$ for $412 \mathrm{~nm}$ ), there was not enough UV light to produce the $100-400 \mathrm{nM} \mathrm{H}_{2} \mathrm{O}_{2}$ observed at depth (Figure 8C). 
Recent work has also demonstrated higher concentrations of $\mathrm{H}_{2} \mathrm{O}_{2}$ at depth than could be accounted for by photochemical processes in deeper waters (Vermilyea et al., 2010; Zhang et al., 2016), suggesting a biological source of $\mathrm{H}_{2} \mathrm{O}_{2}$ in bottom waters Cooper et al. (1989) attributed greater $\mathrm{H}_{2} \mathrm{O}_{2}$ than expected from photochemistry at depth $(\sim 8 \mathrm{~m})$ in Lake Erie to vertical mixing of surface and deep water, especially in the shallow western basin of Lake Erie where strong winds can mix surface water to the bottom. However, in this study, $\mathrm{H}_{2} \mathrm{O}_{2}$ concentrations were similar between surface and bottom waters even at depths $>20 \mathrm{~m}$ during stratified conditions (Figure $\mathbf{8 C}$ ). These results do not rule out photochemical contributions to $\mathrm{H}_{2} \mathrm{O}_{2}$ by CDOM. Instead, the results suggest that photochemical processes are unlikely to explain the high or peak $\mathrm{H}_{2} \mathrm{O}_{2}$ concentrations observed in late July and early August in 2014 and 2015, especially given that during this time the photochemical production by CDOM was lower than during May and June due to lower CDOM and lower solar radiation later in the summer (Figure 12).

The third line of evidence for an important biological role in $\mathrm{H}_{2} \mathrm{O}_{2}$ dynamics in Lake Erie is that $\mathrm{H}_{2} \mathrm{O}_{2}$ concentrations were more strongly aligned with biological processes than with CDOM or water mass movement of CDOM in the western basin (Figures 7, 10). For example, in both 2014 and 2015, $\mathrm{H}_{2} \mathrm{O}_{2}$ concentrations peaked at the end of July just before the peak in the Microcystis bloom that was indicated by $\mathrm{Chl} a$, water column respiration rates, and concentrations of particulate microcystins (Figure 10). The same conditions that favor Microcystis blooms may favor biological production of $\mathrm{H}_{2} \mathrm{O}_{2}$ because while different organisms vary widely in their capacity to produce $\mathrm{H}_{2} \mathrm{O}_{2}$ (Zepp et al., 1987), high light, and total cell abundance are expected to be important controls on biological $\mathrm{H}_{2} \mathrm{O}_{2}$ production (Zepp et al., 1987; Marsico et al., 2015). Reactive oxygen species like $\mathrm{H}_{2} \mathrm{O}_{2}$ are produced by photosynthetic organisms under highlight conditions when light-driven electron transport outpaces electron consumption during $\mathrm{CO}_{2}$ fixation (Latifi et al., 2009). Thus, as photosynthetic biomass increased in Lake Erie during July in the warm and high-light surface waters (Figure 10A), biological production of $\mathrm{H}_{2} \mathrm{O}_{2}$ may have increased.

It is likely that biological production of $\mathrm{H}_{2} \mathrm{O}_{2}$ could account for the high concentrations of $\mathrm{H}_{2} \mathrm{O}_{2}$ observed in Lake Erie during late July and early August because absolute rates of biological production in $\mathrm{H}_{2} \mathrm{O}_{2}$ have been reported to be up to $250 \mathrm{nM} \mathrm{h}^{-1}$ in eutrophic lakes (Marsico et al., 2015). The rate of biological production measured here from microcosm experiments is the net of both biological production and decay, and is thus not directly comparable to photochemical production of $\mathrm{H}_{2} \mathrm{O}_{2}$ by CDOM (photochemical decay is $<5 \%$ of production; (Moffett and Zafiriou, 1993) or comparable to studies using isotopicallylabeled $\mathrm{H}_{2} \mathrm{O}_{2}$ to isolate biological production from decay in natural waters (Vermilyea et al., 2010; Marsico et al., 2015). However, the net rate of biological production measured in this study (30 $\pm 14 \mathrm{nM} \mathrm{h}^{-1}$; Figure 12) was within the range of calculated photochemical production of $\mathrm{H}_{2} \mathrm{O}_{2}$ by CDOM in Lake Erie (8-150 $\mathrm{nM} \mathrm{h}^{-1}$; Figure 12) and within the range of absolute rates of biological production (Marsico et al., 2015). Thus, taking the net rate of biological $\mathrm{H}_{2} \mathrm{O}_{2}$ production in this study as a minimum and assuming that absolute rates of biological production in Lake Erie were on the high end of the range corresponding with other eutropic waters $\left(50-250 \mathrm{nM} \mathrm{h}^{-1}\right.$ Marsico et al., 2015), biological processes could produce the high concentrations of $\mathrm{H}_{2} \mathrm{O}_{2}$ observed in Lake Erie within a few hours especially if decay rates were slow during times leading up to peak $\mathrm{H}_{2} \mathrm{O}_{2}$ concentrations (prior to peak biological activity in Lake Erie, Figure 10).

As biomass increased in the lake leading up to the peak of the bloom in late July and early August, rates of biological decay of $\mathrm{H}_{2} \mathrm{O}_{2}$ may have also increased, thus leading to the relatively low concentrations of $\mathrm{H}_{2} \mathrm{O}_{2}$ from August through October (Figure 10). Recent work has reported high $\mathrm{H}_{2} \mathrm{O}_{2}$ decay rates during dense algal blooms (Marsico et al., 2015), as expected given significant, positive correlations between rates of biological decay of $\mathrm{H}_{2} \mathrm{O}_{2}$ and chlorophyll $a$ and cell abundance (Cooper et al., 1994; Marsico et al., 2015). Furthermore, biological decay has been shown to increase with increasing $\mathrm{H}_{2} \mathrm{O}_{2}$ concentrations (Vermilyea et al., 2010). Increasing rates of biological decay concurrent with increasing biomass and biological production of $\mathrm{H}_{2} \mathrm{O}_{2}$ (Marsico et al., 2015) may be expected because microbes are equipped with anti-oxidant enzymes such as catalase and peroxidase that break down $\mathrm{H}_{2} \mathrm{O}_{2}$ (Giorgio et al., 2007). For example, in coastal waters, catalase, and peroxidase accounted for $\sim 65-80$ and 20-35\%, respectively, of $\mathrm{H}_{2} \mathrm{O}_{2}$ decay (Moffett and Zafiriou, 1990).

Patterns in $\mathrm{H}_{2} \mathrm{O}_{2}$ during the microcosm experiments with Lake Erie water (Figure 13) were consistent with temporal patterns in Lake Erie over the course of the summer. That is, biological production of $\mathrm{H}_{2} \mathrm{O}_{2}$ was $>\mathrm{H}_{2} \mathrm{O}_{2}$ decay during the daylight portion of the experiments (approximately first 8-10 h, Figure 13), while overnight there was relatively greater decay as indicated by zero or low net increase in $\mathrm{H}_{2} \mathrm{O}_{2}$ (Figure 13). It was unlikely that photochemical production contributed substantially to the observed $\mathrm{H}_{2} \mathrm{O}_{2}$ production during these experiments given that photochemical production was calculated to be 3-10 times less than the observed production of $\mathrm{H}_{2} \mathrm{O}_{2}$ (1-10 $\mathrm{nM} \mathrm{h}^{-1}$ see Materials and Methods) The upper limit of photochemical production of $\mathrm{H}_{2} \mathrm{O}_{2}$ from CDOM during these experiments $\left(36 \mathrm{nM} \mathrm{h}^{-1}\right)$ was unlikely given that this estimate assumed that CDOM absorbs all UV light in the experiments; in contrast our results show that on average CDOM absorbed $70 \%$ of the UV light (Figure 9) in Lake Erie, and the ratio of CDOM to total UV absorbance was likely $<70 \%$ in the microcosms given the increase in algal biomass over the course of the experiments. In addition, the apparent quantum yield of $\mathrm{H}_{2} \mathrm{O}_{2}$ formation by CDOM was likely lower than the high value we used in our calculations (Andrews et al., 2000). Instead of photochemical production of $\mathrm{H}_{2} \mathrm{O}_{2}$ by CDOM during these microcosm experiments, the results are more consistent with biological production of $\mathrm{H}_{2} \mathrm{O}_{2}$ under the relatively high-light conditions during the day, with increased $\mathrm{H}_{2} \mathrm{O}_{2}$ decay at night possibly by heterotrophic organisms (Cooper et al., 1994; Marsico et al., 2015). As discussed above, there is evidence in the literature that light may increase the biological production of $\mathrm{H}_{2} \mathrm{O}_{2}$ (Latifi et al., 2009) consistent with net production of $\mathrm{H}_{2} \mathrm{O}_{2}$ during the daylight hours of the microcosm experiments. 
The effect of nutrients on biomass production was apparently decoupled from $\mathrm{H}_{2} \mathrm{O}_{2}$ concentrations during the experiment, given that nutrients significantly increased $\mathrm{Chl} a$ concentrations compared to unamended controls (Figure 14), but did not increase rates of $\mathrm{H}_{2} \mathrm{O}_{2}$ production or $\mathrm{H}_{2} \mathrm{O}_{2}$ concentrations (Figure 13). This may be because as biological production of $\mathrm{H}_{2} \mathrm{O}_{2}$ increases, so does biological decay (Marsico et al., 2015).

\section{CONCLUSIONS AND IMPLICATIONS}

This study demonstrated that $\mathrm{CDOM}$ and $\mathrm{H}_{2} \mathrm{O}_{2}$ concentrations were decoupled and that even the likely upper estimates of photochemical production of $\mathrm{H}_{2} \mathrm{O}_{2}$ by CDOM were too low to account for measured $\mathrm{H}_{2} \mathrm{O}_{2}$ (especially at depths below the photic zone). These results, combined with measured and estimated rates of biological production of $\mathrm{H}_{2} \mathrm{O}_{2}$ that can equal or exceed photochemical production (this study; Marsico et al., 2015), strongly suggest that biological activity is the dominant control on $\mathrm{H}_{2} \mathrm{O}_{2}$ in Lake Erie. Thus, conditions that favor high levels of $\mathrm{H}_{2} \mathrm{O}_{2}$ in Lake Erie were similar to conditions favoring bloom development, i.e., high light and warm water, as predicted by previous studies (O’Neil et al., 2012; Paerl and Otten, 2013). Future work should examine the causes and consequences of high $\mathrm{H}_{2} \mathrm{O}_{2}$ concentrations in Lake Erie and other surface waters where CHABs occur given that in both 2014 and 2015, maximum $\mathrm{H}_{2} \mathrm{O}_{2}$ concentrations occurred just prior to the peak in the Microcystis bloom corresponding with peak biological activity in the lake. These findings support the idea that $\mathrm{H}_{2} \mathrm{O}_{2}$ may exert selective pressure on Microcystis populations that would favor toxic over non-toxic strains (Leunert et al., 2014), possibly because bloomforming cyanobacterial species such as Microcystis aeruginosa produce toxins like microcystins as one mechanism of protection against $\mathrm{H}_{2} \mathrm{O}_{2}$ (Zilliges et al., 2011; Paerl and Otten, 2013). While shifts in the ratio of toxic to non-toxic species or strains has been

\section{REFERENCES}

Abdulla, H. A. N., Minor, E. C., Dias, R. F., and Hatcher, P. G. (2010). Changes in the compound classes of dissolved organic matter along an estuarine transect: a study using FTIR and 13C NMR. Geochim. Cosmochim. Acta 74, 3815-3838. doi: 10.1016/j.gca.2010.04.006

Andrews, S. S., Caron, S., and Zafiriou, O. (2000). Photochemical oxygen consumption in marine waters: a major sink for colored dissolved organic matter? Limnol. Ocean. 45, 267-277. doi: 10.4319/lo.2000.45.2.0267

Apel, K., and Hirt, H. (2004). Reactive oxygen species: metabolism, oxidative stress, and signal transduction. Annu. Rev. Plant Biol. 55, 373-399. doi: 10.1146/annurev.arplant.55.031903.141701

Bridgeman, T. B., Chaffin, J. D., Kane, D. D., Conroy, J. D., Panek, S. E., and Armenio, P. M. (2012). From River to Lake: phosphorus partitioning and algal community compositional changes in Western Lake Erie. J. Great Lakes Res. 38, 90-97. doi: 10.1016/j.jglr.2011.09.010

Brittain, S. M., Wang, J., Babcock-Jackson, L., Carmichael, W. W., Rinehart, K. L., and Culver, D. A. (2000). Isolation and Characterization of microcystins, cyclic heptapeptide hepatotoxins from a lake erie strain of Microcystis aeruginosa. J. Great Lakes Res. 26, 241-249. doi: 10.1016/S0380-1330(00)70690-3 observed during bloom conditions (as discussed in O'Neil et al., 2012), the specific role of $\mathrm{H}_{2} \mathrm{O}_{2}$ in these shifts is as yet unknown.

Relatively lower $\mathrm{H}_{2} \mathrm{O}_{2}$ concentrations observed following peak bloom conditions were consistent with increased biological decay of $\mathrm{H}_{2} \mathrm{O}_{2}$ during this time (Figure 10). Lower $\mathrm{H}_{2} \mathrm{O}_{2}$ concentrations in Lake Erie coincided generally with a shift in CDOM source to more autochthonous organic matter (Figure 6), which has been shown to be more labile to aquatic bacteria compared with CDOM derived from terrestrial organic matter (Cory and Kaplan, 2012; Hosen et al., 2014). Thus, it may be that in eutrophic waters the photochemical influence of CDOM on $\mathrm{H}_{2} \mathrm{O}_{2}$ is less important than DOM's role in fueling bacteria that in turn produce enzymes to decay $\mathrm{H}_{2} \mathrm{O}_{2}$ (Moffett and Zafiriou, 1990; Cooper et al., 1994). Given the similarity in CDOM concentration and sources in Lake Erie compared with Lake Taihu (Zhang et al., 2014; Zhou et al., 2015), a large eutrophic lake in China severely impacted by CHABs every summer (Microcystis), it is likely that the trends reported here for photochemical production of $\mathrm{H}_{2} \mathrm{O}_{2}$ of CDOM and possibly lability of DOM to bacteria may apply to other CHABs-impacted waters.

\section{AUTHOR CONTRIBUTIONS}

RC, TD, GD, TJ, VD, SP, SW, and GK designed the field sampling plans, and all authors contributed to the field work, data analysis, and manuscript preparation.

\section{ACKNOWLEDGMENTS}

We thank Mr. Duane Gossiaux, Ashley Burtner, Danna Palladino, and Derek Smith for field support and NOAA GLERL captains and crew for logistical support. Funding was provided by the U-M Water Center and Fred A. and Barbara M. Erb Family Foundation and in part by NSF CAREER 1351745 (to RMC). This is NOAA GLERL contribution number 1806.

Burns, J. M., Cooper, W. J., Ferry, J. L., King, D. W., DiMento, B. P., McNeill, K., et al. (2012). Methods for reactive oxygen species (ROS) detection in aqueous environments. Aquat. Sci. 74, 683-734. doi: 10.1007/s00027-012-0251-x

Coble, P. G., Green, S. A., Blough, N. V., and Gagosian, R. B. (1990). Characterization of dissolved organic matter in the Black Sea by fluorescence spectroscopy. Nature 348, 432-435. doi: 10.1038/348432a0

Conroy, J. D., Quinlan, E. L., Kane, D. D., and Culver, D. A. (2007). Cylindrospermopsis in Lake Erie: testing its association with other cyanbacterial genera and major limnological parameters. J. Great Lakes Res. 33, 519-535. doi: 10.3394/0380-1330(2007)33[519:CILETI]2.0.CO;2

Cooper, W. J., Lean, D. R. S., and Carey, J. H. (1989). Spatial and temporal patterns of hydrogen peroxide in lake waters. Can. J. Fish. Aquat. Sci. 46, 1227-1231. doi: 10.1139/f89-158

Cooper, W. J., Shao, C., Lean, D. R. S., Gordon, A. S., and Scully, F. E. (1994). "Factors affecting the distribution of $\mathrm{H} 2 \mathrm{O} 2$ in surface waters," in Environmental Chemistry of Lakes and Reservoirs, Advances in Chemistry, ed L. A. Baker (Washington, DC: American Chemical Society), 391-422.

Cooper, W. J., Zika, R. G., Petasne, R. G., and Plane, J. M. (1988). Photochemical formation of hydrogen peroxide in natural waters exposed to sunlight. Environ. Sci. Technol. 22, 1156-1160. doi: 10.1021/es00175a004 
Cooper, W., and Zika, R. (1983). Photochemical formation of hydrogen peroxide in surface and ground waters exposed to sunlight. Science 220, 711-712. doi: $10.1126 /$ science.220.4598.711

Cory, R. M., Crump, B. C., Dobkowski, J. A., and Kling, G. W. (2013). Surface exposure to sunlight stimulates $\mathrm{CO} 2$ release from permafrost soil carbon in the Arctic. Proc. Natl. Acad. Sci. U. S. A. 110, 3429-3434. doi: 10.1073/pnas.1214104110

Cory, R. M., and Kaplan, L. A. (2012). Biological lability of streamwater fluorescent dissolved organic matter. Limnol. Oceanogr. 57, 1347-1360. doi: 10.4319/lo.2012.57.5.1347

Cory, R. M., and McKnight, D. M. (2005). Fluorescence spectroscopy reveals ubiquitous presence of oxidized and reduced quinones in dissolved organic matter. Environ. Sci. Technol. 39, 8142-8149. doi: 10.1021/es0506962

Cory, R. M., McNeill, K., Cotner, J. P., Amado, A., Purcell, J. M., and Marshall, A. G. (2010a). Singlet oxygen in the coupled photochemical and biochemical oxidation of dissolved organic matter. Environ. Sci. Technol. 44, 3683-3689. doi: 10.1021/es902989y

Cory, R. M., Miller, M. P., McKnight, D. M., Guerard, J. J., and Miller, P. L. (2010b). Effect of instrument-specific response on the analysis of fulvic acid fluorescence spectra. Limnol. Oceanogr. Methods 8, 67-78. doi: 10.4319/lom.2010.8.0067

Cory, R. M., Ward, C. P., Crump, B. C., and Kling, G. W. (2014). Carbon cycle. Sunlight controls water column processing of carbon in arctic fresh waters. Science 345, 925-928. doi: 10.1126/science.1253119

Davis, T. W., Bullerjahn, G. S., Tuttle, T., McKay, R. M., and Watson, S. B. (2015). Effects of increasing nitrogen and phosphorus concentrations on phytoplankton community growth and toxicity during planktothrix blooms in Sandusky Bay, Lake Erie. Environ. Sci. Technol. 49, 7197-7207. doi: 10.1021/acs.est.5b00799

Davis, T. W., Watson, S. B., Rozmarynowycz, M. J., Ciborowski, J. J. H., McKay, R. M., and Bullerjahn, G. S. (2014). Phylogenies of microcystin-producing cyanobacteria in the lower Laurentian Great Lakes suggest extensive genetic connectivity. PLoS ONE 9:e106093. doi: 10.1371/journal.pone.0106093

Diaz, J. M., Hansel, C. M., Voelker, B. M., Mendes, C. M., Andeer, P. F., and Zhang, T. (2013). Widespread production of extracellular superoxide by heterotrophic bacteria. Science 340, 1223-1226. doi: 10.1126/science.1237331

Dixon, T. C., Vermilyea, A. W., and Scott, D. T., Voelker, B. M. (2013). Hydrogen peroxide dynamics in an agricultural headwater stream: evidence for significant nonphotochemical production. Limnol. Oceanogr. 58, 2133-2144. doi: 10.4319/lo.2013.58.6.2133

Drábková, M., Admiraal, W., and Maršálek, B. (2007). Combined exposure to hydrogen peroxide and light selective effects on cyanobacteria, green algae, and diatoms. Environ. Sci. Technol. 41, 309-314. doi: 10.1021/es060746i

Dziallas, C., and Grossart, H.-P. (2011). Increasing oxygen radicals and water temperature select for toxic Microcystis sp. PLoS ONE 6:e25569. doi: 10.1371/journal.pone.0025569

Febria, C. M., Lesack, L. F., Gareis, J. A. L., and Bothwell, M. L. (2006). Patterns of hydrogen peroxide among lakes of the Mackenzie Delta, western Canadian Arctic. Can. J. Fish. Aquat. Sci. 63, 2107-2118. doi: 10.1139/f06-106

Fischer, W. J., Garthwaite, I., Miles, C. O., Ross, K. M., Aggen, J. B., Chamberlin, A. R., et al. (2001). Congener-independent immunoassay for microcystins and nodularins. Environ. Sci. Technol. 35, 4849-4856. doi: 10.1021/es011182f

Giorgio, M., Trinei, M., Migliaccio, E., and Pelicci, P. G. (2007). Hydrogen peroxide: a metabolic by-product or a common mediator of ageing signals? Nat. Rev. Mol. Cell Biol. 8, 722-728. doi: 10.1038/nrm2240

Häkkinen, P. J., Anesio, A. M., and Granéli, W. (2004). Hydrogen peroxide distribution, production, and decay in boreal lakes. Can. J. Fish. Aquat. Sci. 61, 1520-1527. doi: 10.1139/f04-098

Helms, J. R., Stubbins, A., Ritchie, J. D., Minor, E. C., Kieber, D. J., and Mopper, K. (2008). Absorption spectral slopes and slope ratios as indicators of molecular weight, source, and photobleaching of chromophoric dissolved organic matter. Limnol. Oceanogr. 53, 955-969. doi: 10.4319/lo.2008.53.3.0955

Hosen, J. D., McDonough, O. T., Febria, C. M., and Palmer, M. A. (2014). Dissolved organic matter quality and bioavailability changes across an urbanization gradient in headwater streams. Environ. Sci. Technol. 48, 7817-7824. doi: $10.1021 /$ es501422z

Jerome, J. H., and Bukata, R. P. (1998). Impact of stratospheric ozone depletion on photoproduction of hydrogen peroxide in Lake Ontario. J. Great Lakes Res. 24, 929-935. doi: 10.1016/S0380-1330(98)70873-1
Kieber, D. J., Miller, G. W., Neale, P. J., and Mopper, K. (2014). Wavelength and temperature-dependent apparent quantum yields for photochemical formation of hydrogen peroxide in seawater. Environ. Sci. Process. Impacts 16, 777-791. doi: 10.1039/c4em00036f

Kutovaya, O. A., McKay, R. M. L., Beall, B. F. N., Wilhelm, S. W., Kane, D. D. Chaffin, J. D., et al. (2012). Evidence against fluvial seeding of recurrent toxic blooms of Microcystis spp. in Lake Erie's western basin. Harmful Algae 15, 71-77. doi: 10.1016/j.hal.2011.11.007

Larson, J. H., Trebitz, A. S., Steinman, A. D., Wiley, M. J., Mazur, M. C., Pebbles, V., et al. (2013). Great Lakes rivermouth ecosystems: scientific synthesis and management implications. J. Great Lakes Res. 39, 513-524. doi: 10.1016/j.jglr.2013.06.002

Latifi, A., Ruiz, M., and Zhang, C.-C. (2009). Oxidative stress in cyanobacteria. FEMS Microbiol. Rev. 33, 258-278. doi: 10.1111/j.1574-6976.2008.00134.x

Lesser, M. P. (2006). Oxidative stress in marine environments: biochemistry and physiological ecology. Annu. Rev. Physiol. 68, 253-278. doi: 10.1146/annurev.physiol.68.040104.110001

Leunert, F., Eckert, W., Paul, A., Gerhardt, V., and Grossart, H. P. (2014). Phytoplankton response to UV-generated hydrogen peroxide from natural organic matter. J. Plankton Res. 36, 185-197. doi: 10.1093/plankt/ fbt096

Marsico, R. M., Schneider, R. J., Voelker, B. M., Zhang, T., Diaz, J. M., Hansel, C. M., et al. (2015). Spatial and temporal variability of widespread dark production and decay of hydrogen peroxide in freshwater. Aquat. Sci. 77, 523-533. doi: 10.1007/s00027-015-0399-2

Matthijs, H. C. P., Visser, P. M., Reeze, B., Meeuse, J., Slot, P. C., Wijn, G., et al. (2012). Selective suppression of harmful cyanobacteria in an entire lake with hydrogen peroxide. Water Res. 46, 1460-1472. doi: 10.1016/j.watres.2011.11.016

McKnight, D. M., Boyer, E. W., Westerhoff, P. K., Doran, P. T., Kulbe, T., and Andersen, D. T. (2001). Spectrofluorometric characterization of dissolved organic matter for indication of precursor organic material and aromaticity. Limnol. Oceanogr. 46, 38-48. doi: 10.4319/lo.2001.46.1.0038

Michalak, A. M., Anderson, E. J., Beletsky, D., Boland, S., Bosch, N. S., Bridgeman, T. B. A., et al. (2013). Record-setting algal bloom in Lake Erie caused by agricultural and meteorological trends consistent with expected future conditions. Proc. Natl. Acad. Sci. U. S. A. 110, 6448-6452. doi: $10.1073 /$ pnas. 1216006110

Miller, W. L. (1998). "Effects of UV radiation on aquatic humus: photochemical principles and experimental considerations," in Aquatic Humic Substances, Ecological Studies, eds D. O. Hessen, L. J. Tranvik (Berlin, Heidelberg: Springer Berlin Heidelberg), 125-143.

Minor, E., and Stephens, B. (2008). Dissolved organic matter characteristics within the Lake Superior watershed. Org. Geochem. 39, 1489-1501. doi: 10.1016/j.orggeochem.2008.08.001

Moffett, J. W., and Zafiriou, O. C. (1990). An investigation of hydrogen peroxide chemistry in surface waters of Vineyard Sound with $\mathrm{H}_{2}^{18} \mathrm{O}_{2}$ and ${ }^{18} \mathrm{O}_{2}$. Limnol. Oceanogr. 35, 1221-1229. doi: 10.4319/lo.1990.35.6.1221

Moffett, J., and Zafiriou, O. C. (1993). The photochemical decomposition of hydrogen peroxide in surface waters of the eastern Caribbean and Orinoco River. J. Geophys. Res. 98, 2307-2313. doi: 10.1029/ 92JC02768

Mostofa, K., Liu, C., Sakugawa, H., Vione, D., Minakata, D., and Wu, F. (2013). "Photoinduced and microbial generation of hydrogen peroxide and organic peroxides in natural waters," in Photobiogeochemistry of Organic Matter, eds K. M. G. Mostofa, T. Yoshioka, A. Mottaleb, and D. Vione (Berlin; Heidelberg: Springer-Verlag), 139-207.

Murphy, K. R., Stedmon, C. A., Graeber, D., and Bro, R. (2013). Fluorescence spectroscopy and multi-way techniques. PARAFAC. Anal. Methods 5, 6557. doi: 10.1039/c3ay41160e

Murphy, K. R., Stedmon, C. A., Waite, T. D., and Ruiz, G. M. (2008). Distinguishing between terrestrial and autochthonous organic matter sources in marine environments using fluorescence spectroscopy. Mar. Chem. 108, 40-58. doi: 10.1016/j.marchem.2007.10.003

O’Donnell, D. M., Effler, S. W., Strait, C. M., and Leshkevich, G. A. (2010). Optical characterizations and pursuit of optical closure for the western basin of Lake Erie through in situ measurements. J. Great Lakes Res. 36, 736-746. doi: 10.1016/j.jglr.2010.08.009 
O’Neil, J. M., Davis, T. W., Burford, M. A., and Gobler, C. J. (2012). The rise of harmful cyanobacteria blooms: the potential roles of eutrophication and climate change. Harmful Algae 14, 313-334. doi: 10.1016/j.hal.2011.10.027

O'Sullivan, D. W., Neale, P. J., Coffin, R. B., Boyd, T. J., and Osburn, C. L. (2005). Photochemical production of hydrogen peroxide and methylhydroperoxide in coastal waters. Mar. Chem. 97, 14-33. doi: 10.1016/j.marchem.2005. 04.003

Obenour, D. R., Gronewold, A. D., Stow, C. A., and Scavia, D. (2014). Using a bayesian hierarchical model to improve Lake Erie cyanobacteria bloom forecasts. Water Resour. Res. 50, 7847-7860. doi: 10.1002/2014WR015616

Ouellette, A. J. A., Handy, S. M., and Wilhelm, S. W. (2006). Toxic Microcystis is widespread in Lake Erie: PCR detection of toxin genes and molecular characterization of associated cyanobacterial communities. Microb. Ecol. 51, 154-165. doi: 10.1007/s00248-004-0146-Z

Paerl, H. W., and Otten, T. G. (2013). Blooms bite the hand that feed them. Science 342, 433-434. doi: 10.1126/science. 1245276

Petasne, R. G., and Zika, R. G. (1987). Fate of superoxide in coastal sea water. Nature 325, 516-518. doi: 10.1038/325516a0

Peterson, B. M., McNally, A. M., Cory, R. M., Thoemke, J. D., Cotner, J. B., and McNeill, K. (2012). Spatial and temporal distribution of singlet oxygen in Lake Superior. Environ. Sci. Technol. 46, 7222-7229. doi: 10.1021/es301105e

Powers, L. C., and Miller, W. L. (2014). Blending remote sensing data products to estimate photochemical production of hydrogen peroxide and superoxide in the surface ocean. Environ. Sci. Process. Impacts 16, 792-806. doi: 10.1039/C3EM00617D

Qian, H., Hu, B., Yu, S., Pan, X., Wu, T., and Fu, Z. (2012). The Effects of hydrogen peroxide on the Circadian rhythms of Microcystis aeruginosa. PLoS ONE 7:e33347. doi: 10.1371/journal.pone.0033347

Qian, H., Yu, S., Sun, Z., Xie, X., Liu, W., and Fu, Z. (2010). Effects of copper sulfate, hydrogen peroxide and N-phenyl-2-naphthylamine on oxidative stress and the expression of genes involved photosynthesis and microcystin disposition in Microcystis aeruginosa. Aquat. Toxicol. 99, 405-412. doi: 10.1016/j.aquatox.2010.05.018

Richard, L. E., Peake, B. M., Rusak, S. A., Cooper, W. J., and Burritt, D. J. (2007). Production and decomposition dynamics of hydrogen peroxide in freshwater. Environ. Chem. 4, 49-50. doi: 10.1071/en06068

Richards, R. P., Baker, D. B., Crumrine, J. P., and Stearns, A. M. (2010). Unusually large loads in 2007 from the Maumee and Sandusky Rivers, tributaries to Lake Erie. J. Soil Water Conserv. 65, 450-462. doi: 10.2489/ jswc.65.6.450

Rinta-Kanto, J. M., Konopko, E. A., DeBruyn, J. M., Bourbonniere, R. A., Boyer, G. L., and Wilhelm, S. W. (2009). Lake Erie Microcystis: relationship between microcystin production, dynamics of genotypes and environmental parameters in a large lake. Harmful Algae 8, 665-673. doi: 10.1016/j.hal.2008. 12.004

Rinta-Kanto, J. M., Ouellette, A. J. A., Boyer, G. L., Twiss, M. R., Bridgeman, T. B., and Wilhelm, S. W. (2005). Quantification of Toxic Microcystis spp. during the 2003 and 2004 Blooms in Western Lake Erie using Quantitative Real-Time PCR. Environ. Sci. Technol. 39, 4198-4205. doi: 10.1021/es048249u

Rusak, S. A., Richard, L. E., Peake, B. M., and Cooper, W. J. (2005). "Long-term trends in steady-state hydrogen peroxide levels in relation to solar radiation in the water of leith, Dunedin, New Zealand," in 2005 International Chemical Congress of Pacific Basin Societies (Honolulu)

Scavia, D., David Allan, J., Arend, K. K., Bartell, S., Beletsky, D., Bosch, N. S., et al. (2014). Assessing and addressing the re-eutrophication of Lake Erie: central basin hypoxia. J. Great Lakes Res. 40, 226-246. doi: 10.1016/j.jglr.2014.02.004

Scully, N., McQueen, D., Lean, D., and Cooper, W. (1996). Hydrogen peroxide formation: the interaction of ultraviolet radiation and dissolved organic carbon in lake waters along a 43-75 degrees N gradient. Limnol. Oceanogr. 41, 540-548. doi: 10.4319/lo.1996.41.3.0540

Sleighter, R. L., Cory, R. M., Kaplan, L. A., Abdulla, H. A, N., and Hatcher, P. G. (2014). A coupled geochemical and biogeochemical approach to characterize the bioreactivity of dissolved organic matter from a headwater stream. J. Geophys. Res. 119, 1520-1537. doi: 10.1002/2013JG002600

Speziale, B. J., Schreiner, S. P., Giammatteo, P. A., and Schindler, J. E. (1984). Comparison of $\mathrm{N}, \mathrm{N}$-dimethylformamide, dimethyl sulfoxide, and acetone for extraction of phytoplankton chlorophyll. Can. J. Fish. Aquat. Sci. 41, 1519-1522. doi: 10.1139/f84-187

Stedmon, C. A., and Bro, R. (2008). Characterizing dissolved organic matter fluorescence with parallel factor analysis: a tutorial. Limnol. Oceanogr. Methods 6, 572-579. doi: 10.4319/lom.2008.6.572

Stedmon, C. A., and Markager, S. (2005). Tracing the production and degradation of autochthonous fractions of dissolved organic matter using fluorescence analysis. Limnol. Oceanogr. 50, 1415-1426. doi: 10.4319/lo.2005.50.5.1415

Stedmon, C. A., Markager, S., and Bro, R. (2003). Tracing dissolved organic matter in aquatic environments using a new approach to fluorescence spectroscopy. Mar. Chem. 82, 239-254. doi: 10.1016/s0304-4203(03)00072-0

Steffen, M. M., Belisle, B. S., Watson, S. B., Boyer, G. L., and Wilhelm, S. W. (2014). Status, causes and controls of cyanobacterial blooms in Lake Erie. J. Great Lakes Res. 40, 215-225. doi: 10.1016/j.jglr.2013.12.012

Stephens, B. M., and Minor, E. C. (2010). DOM characteristics along the continuum from river to receiving basin: a comparison of freshwater and saline transects. Aquat. Sci. 72, 403-417. doi: 10.1007/s00027-010-0144-9

Tassan, S., and Ferrari, G. M. (2003). Variability of light absorption by aquatic particles in the near-infrared spectral region. Appl. Opt. 42:4802. doi: 10.1364/AO.42.004802

Vermilyea, A. W., Hansard, S. P., and Voelker, B. M. (2010). Dark production of hydrogen peroxide in the Gulf of Alaska. Limnol. Oceanogr. 55, 580-588. doi: 10.4319/lo.2009.55.2.0580

Weishaar, J. L., Aiken, G. R., Bergamaschi, B. A., Fram, M. S., Fujii, R., and Mopper, K. (2003). Evaluation of specific ultraviolet absorbance as an indicator of the chemical composition and reactivity of dissolved organic carbon. Environ. Sci. Technol. 37, 4702-4708. doi: 10.1021/es030360x

Wetzel, R. G. (1992). Gradient-dominated ecosystems - sources and regulatory functions of dissolved organic matter in freshwater ecosystems. Hydrobiologia 229, 181-198. doi: 10.1007/BF00007000

Winterbourn, C. C. (2013). "Hydrogen peroxide and cell signaling, Part C," in Methods in Enzymology, eds E. Cadenas and L. Packer (San Diego: Elsevier).

Yocis, B. H., Kieber, D. J., and Mopper, K. (2000). Photochemical production of hydrogen peroxide in Antarctic Waters. Deep Sea Res. Part I Oceanogr. Res. Papers 47, 1077-1099. doi: 10.1016/S0967-0637(99)00095-3

Zepp, R. G., Skurlatov, Y. I., and Pierce, J. T. (1987). Photochemistry of Environmental Aquatic Systems, ACS Symposium Series. Washington, DC: American Chemical Society.

Zhang, F., Harir, M., Moritz, F., Zhang, J., Witting, M., Wu, Y., et al. (2014). Molecular and structural characterization of dissolved organic matter during and post cyanobacterial bloom in Taihu by combination of NMR spectroscopy and FTICR mass spectrometry. Water Res. 57C, 280-294. doi: 10.1016/j.watres.2014.02.051

Zhang, T., Hansel, C. M., Voelker, B. M., Lamborg, C. H. (2016). Extensive dark biological production of reactive oxygen species in brackish and freshwater ponds. Environ. Sci. Technol. 50, 2983-2993. doi: 10.1021/acs.est.5b03906

Zhou, Y., Zhang, Y., Shi, K., Niu, C., Liu, X., and Duan, H. (2015). Lake Taihu, a large, shallow and eutrophic aquatic ecosystem in China serves as a sink for chromophoric dissolved organic matter. J. Great Lakes Res. 41, 597-606. doi: 10.1016/j.jglr.2015.03.027

Zilliges, Y., Kehr, J.-C., Meissner, S., Ishida, K., Mikkat, S., Hagemann, M., et al. (2011). The cyanobacterial hepatotoxin microcystin binds to proteins and increases the fitness of microcystis under oxidative stress conditions. PLOS ONE 6:e17615. doi: 10.1371/journal.pone.0017615

Conflict of Interest Statement: The authors declare that the research was conducted in the absence of any commercial or financial relationships that could be construed as a potential conflict of interest.

Copyright (c) 2016 Cory, Davis, Dick, Johengen, Denef, Berry, Page, Watson, Yuhas and Kling. This is an open-access article distributed under the terms of the Creative Commons Attribution License (CC BY). The use, distribution or reproduction in other forums is permitted, provided the original author(s) or licensor are credited and that the original publication in this journal is cited, in accordance with accepted academic practice. No use, distribution or reproduction is permitted which does not comply with these terms. 